\title{
Negative Effects of Media on Children and Youth' Socialization Process: A Study on Violent and Aggressive Behaviors
}

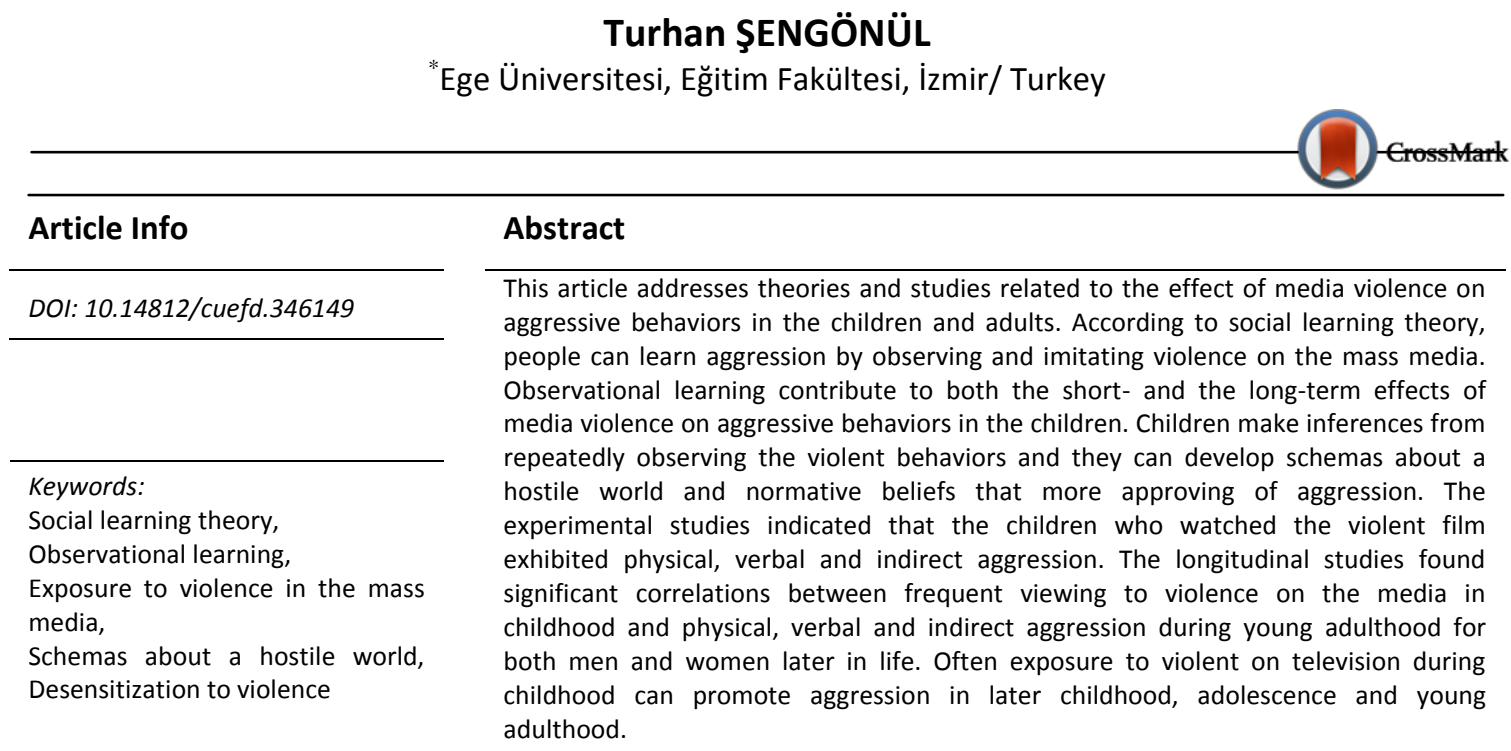

\section{Medyanın Çocukların ve Gençlerin Sosyalleşme Sürecine Olumsuz Etkileri: Şiddet ve Saldırgan Davranışlar Üzerine Bir İnceleme}

\section{Makale Bilgisi}

DOI: $10.14812 /$ cuefd.346149

Anahtar Sözcükler:

Sosyal öğrenme teorisi,

Gözlemsel öğrenme,

Kitle iletişim araçlarındaki şiddete

maruz kalma,

Düşmanca dünya şemaları,

Şiddete duyarsızlaşma

\section{Öz}

$\mathrm{Bu}$ makale medyadaki şiddetin çocuklarda ve gençlerde saldırgan davranışlar üzerindeki etkisi ile ilişkili teorileri ve araştırmaları ele almaktadır. Sosyal öğrenme teorisine göre insanlar kitle iletişim araçlarındaki şiddeti gözlemleyerek ve taklit ederek saldırganlığı öğrenebilmektedirler. Gözlemsel öğrenme medyadaki şiddetin çocuklardaki saldırgan davranışlar üzerine hem kısa süreli hem uzun süreli etkilere katkı yapmaktadır. Çocuklar şiddet davranışlarını tekrar tekrar gözlemlemekten çıkarımlar yapmaktalar ve saldırganlığı daha çok onaylayan normatif inançlar ve düşmanca dünya şemaları geliştirebilmektedirler. Deneysel çalışmalar şiddet filmi seyretmiş çocukların fiziksel, sözlü ve dolaylı saldırganlık gösterdiklerine işaret etmişlerdir.Boylamsal çalışmalar hem erkekler hem kızlar için çocuklukta medyadaki şiddeti sık sık izleme ile daha sonraki yaşamda genç yetişkinlikte fiziksel, sözlü ve dolaylı saldırganlık arasındaki anlamlı ilişkileri bulmuşlardır. Çocuklukta televizyondaki şiddete çok kez maruz kalma, daha sonraki çocukluktaki, ergenlikteki ve genç yetişkinlikteki saldırganlığı ilerletebilmektedir.

* Author: turhan.sengonul@ege.edu.tr 


\section{Introduction}

Increasing availability of new and interactive communication technologies and mass communication media in the $20^{\text {th }}$ and $21^{\text {st }}$ centuries has been seen as a radical and noteworthy change in not only the society but also the social world. Media sources such as the television, radio, films, video games, tape cassettes and computer web sites play important roles in the lives of children and adolescents and largely affect values, beliefs and behaviour. Research studies have revealed that watching violence in television is one of the factors independently contributing to the development of aggressive behavior.Exposure to media violence increases the risk of aggressive and violent behaviour in viewers. Aggression has been defined as a certain act carried out and directed to intentionally inflict harm on another individual. The aggressive person believes that the aggressive behavior will inflict harm on the target individual and that he is motivated to avoid such aggressive behaviours (Anderson and Bushman, 2002b; Berkowitz, 1993; Geen, 2001; Swing and Anderson, 2010). Aggressive behaviour does not always occur in physical form and nature. Psychologists distinguish less serious forms of aggression such as verbal retaliation, engagement in spreading rumors or insulting people, and profanity (Ostrow and Godleski, 2010). Relational or social aggression intends to inflict emotional rather than physical harm on a person. Social aggression is observed more among girls as compared to girls boys (Spieker, Campbell, Vandergrift et al., 2012). Media violence has been defined as visual portrayal of physical aggression carried out by a person to harm another and refers to aggressive and violent behaviour portrayed through story characters in the media. Those characters could be human or non-human and cartoonish or visually realistic, emerging as unrealistic, fictional, animated or realistic violence (Huesmann and Taylor, 2006; Gentile, Saleem and Anderson, 2007; Swing and Anderson, 2010). The results of over 2,000 scientific studies and reviews has shown that higher habitual exposure to media violence increases the risk of aggressive behaviour in certain children and adolescents, desensitizesthem towardsviolence, and leads them to believe thatthe world is a "crueler and more terrifying place" to live in (Strasburger, Wilson and Jordan, 2014).

TV viewing frequency in the family or leisure time TV viewing frequency affects the degree of children's exposure to the violence portrayed on television.Children and youth between the ages 13 and 19 spend more time with various media compared to certain activities they engage in except for sleeping (American Academy of Pediatrics, 2010). Young people spend more than 7 hours a day using various different media. A study conducted by Kaiser Family Foundation on over 2,000 individuals between the ages 8 and 18 (2010) has revealed that children and young people in the United States of America spend an average of over 7 hours a day with media (Rideout, Foehr and Roberts, 2010).According tothe United StatesofAmericaNational Report, approximately two thirds of children and babies under the age of 2 are exposed to TV viewing for a period of 30-60 minutes a day. Spending time with media has been replacing engagement in creative, active and social activities (Vandewater, Rideout, Wartella et al., 2007). Preschool kindergarten children spend a lot more time for watching shows-entertainments compared to reading, learning new things and playing outdoor games (Rideout, Vandewater and Wartella, 2003). Preschoolers and school-age children watch TV for 2 to 4 hours a day and during those prime-time evening programs, five violent acts are portrayed each hour. Children's Saturday morning programs have the highest rate of violence during which an average of 20-25 violent acts are portrayed in a period of one hour.The children's programs have a higher frequency of violence compared to comedy programs, music videos and reality shows (Gentile, Saleem and Anderson, 2007). A study conducted by Radio and Television Supreme Council (RTUK) on 2570 people revealed that daily TV viewing frequency was an average of over 4 hours for adults and children (RTUK, A Study on Television Viewing Trends-2, 2009). In another study on levels of violence, in which a total of 5,600 seconds from 80 films shown in five private television channels in Turkey was examined during 16.00-21.30 on weekdays and 09.00-21.30 on weekends, the rate of violence was found to be $33.1 \%$ (Ayrancl, Köşgeroğlu, Günay, 2004). The study also emphasized the prevalence of media violence and the ways in which violence was portrayed on television. While $60 \%$ of television programs contain violence (Wilson, Kunkel, Linz et al., 1998), violence is portrayed in 90\% of video games (Children Now, 2001).Television violence is often made attractive for the viewers and $96 \%$ of all violent programs use aggression as a 
cinematographic tool for the sole purpose of entertaining viewers.44\% of violence interactions were made through aggressive individuals who had certain valuable attractive characteristics to encourage imitation. $40 \%$ of those who displayed aggressive behaviour were people who served as role models for young viewers and who had "good" characters or characteristics. Thus, television violence has been made attractive for the viewers. $71 \%$ of violent scenes did not portray regret, remorse, criticism or punishment for the person displaying violent behaviours and $86 \%$ did not include scenes showing bloody wounds and horn butting. Approximately one half of television violence did not inflict any harm or cause any pain in the victim and only $16 \%$ of violence programs reflected long-term negative impacts related to the victim or the victim's family. Better half of the violence scenes included physical violence, which can be lethal in real-life, by trivializing violence and approximately $40 \%$ portrayed direct violence or used characters committing violence; whereas $75 \%$ gave priority to scenes punishing or convicting the person who were involved in violence. Almost $45 \%$ of all the programs included "bad" characters that were never punished or rarely punished for the aggressive acts they committed. $40 \%$ of the violence scenes contained some forms of comedy and entertainment and only less than $5 \%$ delivered anti-violence messages. All the violence in the main stories on television was portrayed as something attractive and appraisable. In television, films and video games, aggression was used as a form of punishment given to bad people for supposedly good reasons. $44 \%$ of violent acts were presented in a manner that could be described as "justified" (Wilson, Kunkel, Linz et al., 1998). Television violence targeted children in particular. While $57 \%$ of the shows not targeting children contained violence, approximately $70 \%$ of children's shows were quite violent. $36 \%$ of people demonstrating violent acts had attractive personality traits. $30 \%$ of violence was described as "justified" and $81 \%$ of violent scenes did not portray any punishment for aggressors(Wilson, Smith, Potter et al., 2002). In 34\% of violent scenes, harm inflicted upon the victim was portrayed in an unrealistic way. Unrealistic harm was most frequently seen in children's programs as was the case in the cartoons(Wilson, Kunkel, Linz et al., 2002, 1998). Another analysis of violence content revealed that some forms of aggression were portrayed in most ( $88 \%$ ) of the television programs that were popular among the $5^{\text {th }}$ grade girls. $77 \%$ of the programs portrayed indirect aggression, $71 \%$ contained physical aggression and $69 \%$ included verbal aggression. On the other hand, $60 \%$ of all the acts were portrayed as physical aggression, $23 \%$ as indirect aggression and $17 \%$ as verbal aggression. At this point, 10 acts of physical aggression were observed per hour. When compared to other programs in which 6 acts of violence were portrayed, a typical hour of programs targeting children contained 14 different acts of violence. Violence in children's programs was portrayed in a more humorous manner as in the cartoons (Linder and Lyle, 2011). In a content analysis of 50 programs most popular among children between the ages of 2 and 11, it was shown that social aggression was quite prevalent and $92 \%$ of the shows contained social aggression. While all other programs contained 4 violent acts per hour, 14 different violent acts were portrayed in children's programs (Martins and Wilson, 2012a). Violent roles were portrayed more in children's programs as entertainment. Most of the programs targeting children were animated cartoons (Strasburger and Wilson, 2014).

\section{Objective and Significance of the Study}

The present article aims to deal with not only experimental and field studies but also theories seeking to explain the effects of viewing media violence in childhood on aggressive behaviour in later years. Relationships between more frequent and intensive exposure to media violence in childhood and demonstrating aggressive behaviour in later years have been discussed within the framework of observational learning and imitation and on the basis of experimental and field studies as a theoretical background. In today's society, proliferation of violence and aggressive behaviour continues to exist as a social problem. When the contribution of viewing media violence to violence and aggressive behaviours in later years is exposed on the basis of theoretical views as well as experimental and longitudinal, some of the underlying causes of violence and aggressive behaviours can be understood to a certain extent. Once the underlying causes and mechanisms of violence and aggressive behaviours developing in viewers as a result of harmful effects of exposure to media violence are known, governments, 
politicians, the media industry, schools and families can generate solutions to this problem by taking certain initiatives aimed at protecting children from the harmful effects of media violence.

Method, Data Collection Technique and Research Process in the Studies Examined

Longitudinal research dealing with experimental research studies on the short-term effects of viewing violence and aggressive behaviours in the media and films on the aggressive behaviours in children and youths as well as the impact of greater exposure to media violence in childhood on aggressive behaviours in late childhood, adolescence and emerging adulthood are introduced and described in this study. Data in experimental research are obtained by observing physical aggressive behaviours such as hitting, wrestling, hassling when children viewing and not viewing violence play together in a room (Bjorkqvist, 1985) or aggressive behaviours such as hitting, tripping, kneeing, elbowing, hair pulling and insulting during a game of floor hockey (Josephson, 1987). Aggressive behaviours in children were observed by comparing the periods before and after the introduction of TV into the household (Joy, Kimball and Zabrack, 1986). Longitudinal studies included interviews with school children between the ages of 6-11 and their parents, and each child reported peers engaged in 10 aggressive behaviours in a classroom environment such as "starting a fight over nothing" and "pushing and shoving other children" within the frame work of a scale in which children reported aggressive peers; namely, the Peer-Rate Index of Aggression. The data related to the frequency of viewing violence were obtained by presenting children with a list of television programs with and without physical violence and asking them to check the programs they watched "all the time", "sometimes but not all the time" or "once in a while" (Huesmann and Eron, 1986). Presenting two aggressive males and two aggressive females such as "The Bionic Woman" and "The Six Million Dollar Man", children were asked how much they loved the various adult aggressive characters or how much they acted like them. The data related to children's identifying themselves with the aggressive behaviour on television were collected by receiving different answers such as "2=a lot, $1=a$ little, $0=$ not at all" (Huesmann and Eron, 1986). Children were asked to rate how realistic they judged various violent programs to be. The rating scale was as follows: " $3=$ just like as it in real life, 2= a little like as it in real life; $1=$ not at all as it in real life". Data related to intellectual ability, assumed to be effective on the television viewing habits of children, were obtained from school records. The California Achievement Test (Tiegs and Clark, 1970)was administered to all third grade students and the Oak Park Reading Readiness Test was used for the first and second grade students in order to assess the intellectual ability in childhood. Warner, Meeker and Eells' Socio-economic Status (SES) Scale (1960) was used to collect data related to the parent variable based on information provided by the parents on their levels ofsocio-economic status and education. Aggressive behaviours of the parents were assessed using the Minnesota Multiphasic Personality Inventory (Huesmann, Lefkowitz and Eron, 1978), and aggressive behaviours were measured by three items about how many times in the last year the parents (1) had choked, punched or beaten another adult; (2) slapped or kicked another adult; or (3) threatened or actually cut someone with a knife, or threatened or shot at someone with a gun(Huesmann, Eron, Lefkowitz et al., 1984). Fantasizing about aggression was assessed with the adult version of the Aggression Scale of the Children's Fantasy Inventory (Rosenfeld, Huesmann, Eron et al., 1982). While child-rearing methods and attitudes were assessed using criteria such as (1) rejection of the child, (2) rearing of the child, (3) severe punishment of the child, (4) mobility direction (e.g. desire for success), the television viewing frequency of the parents were determined by means of holding interviews with the parents themselves, their reporting the programs they watched and their assessing those programs (Huesmann and Eron, 1986). As longitudinal investigations required comparison of childhood and adolescence, data related to both periods of the same participants were collected.Most of the boys and girls were contacted by tracing the records in order to complete the research. Moreover, these individuals, their spouses and friends were interviewed and certain data were obtained from the state archives. When the children whose data belonging to the period between the ages of 6 and 11 grew up and reached their 20s were contacted again personally or by telephone, the data related to aggressive behaviour in adulthood were collected from three different sources, namely, self reports, other people and state archives. Based on self-reports about three favorite television programs they regularly or frequently watched, frequency of viewing violence was determined via a rating scheme ranging from 0 
(= no visible violence or slight invisible, or implied violence) to 4 (= high visible violence). Indirect, verbal and slight physical aggression was rated via self-reports about various behaviours the participants were engaged in when "they were in conflict or angry with another person". Indirect aggression was measured via self-reports about how often the participants engaged in behaviours such as "taking other people's things" and "trying to hit other people who disliked them", and verbal aggression was determined via self-reports about how they demonstrated behaviours such as "calling another person names" and "despising and degrading physical abilities and appearance of another person". Slight aggression, on the other hand, was measured via self-reports in which the participants were asked to answer a question consisting of three items such as "how often they hit, kicked and shoved others" (Bjorkqvist, Osterman and Kaukiainen, 1992). The General Aggression Scale included 12 items based on the original peer-nomination scale for children and was also adapted and rewritten for adults. It included such questions as "How often do you give the finger to others?", "How often do you start a fight over nothing?" and "How often do you take other people's things without asking?". The response scale for all of these frequency measures ranged from $0=$ never to $4=$ very often(Huesmann and Eron, 1986). The severe physical aggression scale included three items about how many times in the last year the participant had "choked, punched, or beaten another adult," had "slapped or kicked another adult," or had "threatened or actually cut someone with a knife or threatened or shot at someone with a gun (Huesmann, Eron, Lefkowitz et al., 1984). Using Straus's Conflict Tactics Scale (Straus, Gelles and Steinmetz, 1980), the participants were also asked to report how frequently they aggressed against their spouse (or significant other) (Straus, Gelles and Steinmetz, 1980), and they were assessed on antisocial/aggressive character traits (Huesmann, Lefkowitz, Eron et al., 1978). Various relevant questions were directed to the participants and they were asked to report their frequency of traffic violations and of committing different kinds of specific crimes and whether they had ever been arrested or convicted.

\section{Explaining Acquistion of Aggressive Behaviours on The Basis of Social Learning Theory}

The impact of viewing media violence on aggressive behaviours was described within a theoretical framework on the basis of observational learning and imitation. Social learning or observational learning and imitation play a fundamental role in the acquisition of a social behaviour such as aggression; furthermore, the learning process becomes stronger and people learn to behave aggressively by observing or imitating others (Bandura, 1977). Children enter into social interaction with many sources such as their parents, peers and older siblings in the playground, observe fictional characters on television and films and then display these behaviours themselves (Bandura, 2001). It is known that people have an internal tendency to copy what they observe and possess certain pre-designed neurological systems, and these neurological systems include a special physiological system to learn by imitating (Rizzolatti and Craighero, 2004; Rizzolati, Fadiga, Gallese et al., 1996). The observer (a) notices and looks at the model behaviour, (b) symbolically retains the model behaviour in memory, and encodes it visually and verbally, (c) replicates the behavior, and (d) considers the consequences of the behaviour s/he will perform (Bandura, 1977). Behavioral models are retained in memory in a symbolic manner. Observational learning is based on fantasizing and self-expression. Behaviours are retained in memory by fantasizing. Emotional stimulation leads to perception of external events.As a result of repeated exposure, the stimulant reflects continuous and attainable images of the model performance (Bandura, 1986), and thus images of the models can be collected and displayed in the absence of physical beings. Based on an activity which is observed repeatedly, a fantastic replica of the model can be created (Liebert and Spiegler, 1990).Visualisation plays a fundamental role in the first phase of observational learning in the absence of expressive skills. Cognitive contents are generally expressive rather than visual. Details of an observed behaviour are acquired via transformation of visual information into verbal codes or expressions, retained in memory and then performed (Bandura, 2001). Observational learning and retaining information in memory are made easier with symbolic codes as they carry much of the information the way they are originally stored. Modeled activities are transformed into images and verbal symbols of expression that can be used at once, and these memory codes serve as guides for performance (Liebert and Spiegler, 1990).In addition to symbolic coding, repetition, or rehearsal also 
serves as an important memory support. When people repeat, rehearse or actually perform modeled behaviours in their minds, they forget less compared to those who do not think about or perform what they see (Bandura, 1997).

Bandura argued that imitation is the key to social learning. He also reported that individuals made cognitive inferences based on observations as well as imitating certain social behaviors which they saw, and that these inferential judgments led to generalization in behaviours. How children interpret events and how they feel when they perform the actions they observe have gained importance (Bandura, 1986). Observing a parent hitting another parent increases not only the possibility of a child hitting another but also the belief that hitting can be acceptable when a person provokes you (Bushman and Huesmann, 2010). Children draw inferences from the behaviours they observe and develop beliefs about the appropriateness of certain behaviours. When children see that an individual solves a social problem by behaving aggressively, they create and retain a script in their minds about aggression and develop a belief that such behaviours are acceptable. When they decide to use the script later, they retrieve it and may behave in the similar manner more often (Guerra, Huesmann and Spindler, 2003; Huesmann and Kirwil, 2007). Huesmann (1988) drew attention to scripts as concepts related to cognitive schemata in aggressive behaviour analyses and also argued that aggressive behaviour was controlled to a great extent by scripts that are encoded, rehearsed, stored, retained and recalled in much the same way as are scripts for intellectual behavior.Children learn more generalizing and complex social scripts from the models as a series of rules to interpret, comprehend and deal with certain behaviours and various situations such as conflict (Huesmann, 1998). When learned, such scripts function as a cognitive predictor for future behaviours. For instance, children learn that aggression can be used for trying to solve interpersonal conflicts by observing people who exhibit violent behaviour. As a result of mental repetitions such as fantasizing this type of behavior or multiple exposures to violence, an attitude towards solving this conflict is retained in memory and then easily retrieved. Particularly, observing the violence in the environment affects the children's world schemata and causes them to perceive other's actions as hostile (Gerbner, Gross, Morgan et al., 1994). According to Dodge and his colleagues (1995) inferences drawn from repeated observations have revealed that children develop hostile or positive judgments about the world as well as beliefs related to acceptable types of behaviour.Frequent observation of violence affects children's world schemata with respect to "hostility". They consider other's actions as hostile and such considerations increase the possibility of children's violent behaviors in later years. Similarly, Huesmann and Guerra (1997) emphasized that repeated observations of violent role models in the media as well as in real life motivated children to develop normative beliefs about the appropriateness of aggression and acquire social scripts on how they would behave aggressively. Normative beliefs are viewed as cognitive abstractions of knowledge acquired through observation, experience, and direct tuition, and refer to an individual's own cognitions or cognitive standards about the acceptability or unacceptability of a behavior. Beliefs may be situation specific or general. An example of a situation-specific normative belief would be "It's okay to hit others if they hit you first.", whereas "It's okay to hit others." reflects a general belief.As children develop into adults, their social-cognitive schemata about the world around them begin to become more detailed, normative beliefs on which social behaviors are appropriate become more distinctive and these beliefs begin to act as filters to limit inappropriate social behaviours. Social scripts acquired via observation of families, peers, social groups and mass communication media become more complex and automatic in application (Huesmann and Guerra, 1997). As noted by Crick and Dodge (1994), responding is governed by ethical standards and values related to beliefs about the acceptability of a behaviour. People who have normative beliefs that are more approving of aggression can become more aggressive. Not only normative beliefs approving of aggression but also actual aggressive behavior increase with age during the elementary school years (Huesmann and Guerra, 1997).

Another approach describing the long-term effects of exposure to media violence on aggressive behavior is called the theory of desensitization. Recent research established a relationship between exposure to violence and desensitization (Bailey, West and Anderson, 2011). Repeated exposure to emotional stimuli such as the media and video games may lead to habituation of certain natural emotional responses or "desensitization". Despite expectations that blood wounds, horn butting or 
other scenes with painful consequences would curb aggression, research has revealed that such scenes could increase aggression in some of the viewers. Repeated exposure to such negative consequences can desensitize individuals to blood wounds, horn butting and other scenes and images causing pain to the victim. Behaviours that are observed in a non-habitual manner at first begin to look normative to children after they view them repeatedly. Emotions children feel as a reaction to a certain scene tend to decrease in intensity after exposure to that particular scene repeatedly. When they observe blood, gore, horn butting and violence, most humans seem to have an innate negative response. Increased heart rates, perspiration and discomfort may accompany such exposure. With repeated observation of and exposure to violence, such negative emotional responses habituate and children become desensitized. Such habituation may effectively eliminate the punishment for natural consequences of media violence. Children may think about and enact an aggressive response later without experiencing such negative emotions. Consequently, aggression becomes more likely to occur. Experimentally, violence viewers who gave a negative emotional response less strongly behaved much more aggressively compared to those who gave negative emotional responses more strongly(Moise-Titus, 1999; Kirwil and Huesmann, 2003). Individuals who consume a lot of violent media become less sympathetic to victims of violence. In one study, people who played violent video games assigned less harsh penalties to criminals than those who played nonviolent games (Deselms and Altman, 2003). People exposed to media violence attributed less injury to the victims (Linz, Donnerstein and Adams, 1989), and showed less empathy (Linz, Donnerstein and Penrod, 1988). People who showed less empathy to the victims of violence were also less willing to help a victim in real life (Molitor and Hirsch, 1994). Children exposed to violent television programs behaved less willing in intervening a fight between two little kids. Similarly, adults were also less willing to help the needy after they were exposed to media violence (Bushman and Anderson, 2009). Due to desensitization to violence over time, people have become more tolerant to violence and less sympathetic to the victims of violence. Research consistent with such comments stated that people showed less psychological arousal to real display of violence in the process of more exposure to media violence (Carnagey, Anderson and Bushman, 2007). While empathy calls for adopting the perspective of the victim, video games promote adopting the perspective of the aggressor. It is observed that playing violent video games has a strong effect in decreasing the empathy the player feels for the victim (Bushman and Anderson, 2009).

\section{Factors Increasing The Impact of Media Violence on Children}

Neurologists and cognitive psychologists maintain that human memory often functions and acts as a network comprised of webs, nodes and connections associated with thoughts partially stimulated and shaped by relative stimulants in their environment. Nodes represent concepts, and connections refer to interconceptual relationships and associations. Thoughts, emotions and behavioral tendencies are all interconnected in the memory. Exposure to stimuli can shape or activate memory concepts (Fiske and Taylor, 1991). Giles (2003) defines this preparation phase as the stimulation or reactivation of memories related to violent scenes when appropriate cues have been provided. A lot of factors either enhance or diminishthe risk of harmful effects associated with viewing violent portrayals (Wilson, Kunkel, Linz et al., 1998). According to Associative Cognitive Theory, cognitive cues may lead to more violent behaviour. Concepts that exist in the usual way are interconnected in the memory and are used to interpret stimuli. For example, when an individual associates a gun with killing or wounding another person rather than with a non-violent use in the shooting sports, the gun increases the possibility of behaving in a much more violent manner (Bartholow, Anderson, Carnagey et al., 2005). Mutlu (1999) has stated that violent portrayals on television prepare violent thoughts for later use by viewers and trigger violent behaviour in children. Viewers are warned against the violence observed in real life and on media as psychological excitation such as heart rate and blood pressure might increase. It is observed that aggression can be rapidly enhanced due to two possible causes of excitation, which are (a) excitation transfer or conduction (Zillmann, 1983) and (b) general excitation (Berkowitz, 1993). Theories related to cognitive development affirmed that social scripts, schemata and beliefs of smaller children became less evident and grew more vulnerable to the effects of exposure to media violence. As children have fewer welldeveloped neurological and emotional systems as well as less well-developed personality, they can 
change more readily when exposed toharmful effects associated with repeated exposure to violent portrayals. It was observed that smaller children were more vulnerable and exposed to the long-term effects of portrayal of violence(Huesmann, Moise-Titus, Podolski et al., 2003; Paik and Comstock, 1994). According to some neuro-anatomists, excessive television viewing (more than five hours per day, seven days a week) can have a serious toll on a child's cognition. The limbic system of the brain or the sensory part is referred to as the image-making center. They argue that the limbic system develops more slowly when children spend half of their life in front of a television set. A strong limbic system provides a natural defense against the constant violent images (Slotsve, del Carmen, Sarver et al., 2008). Some neuroimaging studies have established that excessive exposure to television violence impairs development of parts of the brain associated with prefrontal cortex and excitation. Excessive consumption of media violence delays development of frontal and limbic regions of the brain and plays an important role in diminishing the activity in the prefrontal mechanisms controlling emotions and behaviours, thus causing a long-term increase in aggression and decrease in preventive control. Emotions are regulated via activation of prefrontal regions with emotion-sensitive limbic areas (Banks, Eddy, Angstadt et al., 2007). As prefrontal cortex doesn' $t^{\prime}$ mature in childhood and adolescence, excessive exposure to media violence disrupts prefrontal-limbic communication and creates some negative impacts on emotion regulation (Hummer, 2015). As many developmental psychologists theorized, Paik and Comstock (1994) indicated that media violence had a greater impact on children younger than 5 years of age. Developmental psychologists assert that younger children have fewer cognitive skills, experience difficulty differentiatingbetweenfantasyandreality, and have less real-life experience. Nevertheless, researchers argue that there is little evidence to suggest that younger children are more vulnerable to the harmful effects of media violence(Gentile, Saleem and Anderson, 2007). The conception that the viewer's age is a significant variable in his/her level of liability during exposure to media violence seems quite complex. The dimensions of the effects of media violence consistently decrease as the age of a viewer increases (Huesmann and Taylor, 2006). The level of vulnerability, which is generally consistent among university students, is higher than that of children in middle childhood (ages6-11). Despite the fact that smaller children are more vulnerable to the harmful effects of media violence, aggressiveness can change with age. In a research study aimed at measuring responses given to the same stimulus at different ages, primary school children and university students were assigned to play the same violent and non-violent video games and they later demonstrated the same aggressive behaviours. Both children and adolescents became more aggressive after playing violent video games (Anderson, Gentile and Buckley, 2007). Researchers argue that socio-economic status and intellectual abilityof viewers play a fundamental role in consuming television violence. As compared to children of higher socio-economic status and intellectual ability, those with lower socioeconomic status and intellectual abilitywatch more television and witness more television violence most probably due to various reasons including disappointment with social norms, entertainment and other tasks requiring more intellectual interest and effort. Parents' television habits and child rearing practices influence a child's television habits (Comstock and Paik, 1991). Such parenting factors as harsh punishment, rejectionof the child, and lack of discipline also contribute to the child's aggression (Tremblay, 2000). AlthoughComstock and Paik (1991) reported that children in lower socio-economic status viewed more television and consumed moretelevision violence on the average than did children in higher socio-economic status, Huesmann and his colleagues (2002) emphasized that the connection between the socio-economic status and television viewing did not provide an explanation for the general relationship between viewing media violence and criminal behaviours of young adults. Huesmann and Taylor (2006), on the other hand, affirmed that children in lower socio-economic status were more likely to behave aggressively in adulthood as they had been more exposed to media violence in childhood.

In a family atmosphere, parents play an important role in children's consumption of media violence. Children's experience of exposure to media violence primarily takes place in the house. Their television habits develop early in life and become permanent over time. Presence of other people while viewing media violence either facilitates or prevents development of aggressive behaviour in children. In particular, co-viewing television with other people approving of the violence that is portrayed on 
television facilitates aggressive behaviour, whereas co-viewing with other people disapproving of violence can prevent aggressive behaviour (Berkowitz, 1986). Sometimes parents are not aware of the contents of the programs their children constantly watch and do not control the effects of images; for example, they miss some opportunities such as providing comments on the story and disapproving of the tools of violence used to settle conflicts. Relatively, few parents establish explicit rules exercising restrictions over the amount and number of shows, prevent their children from watching violence or provide comments on the content of the programs (Wright, Peters and Huston, 1990). Parents who watch television with their children and discuss the content of the programs are likely to approach child rearing strategies that make use of reasoning and explain rules, and address their children's pride (Abelson, 1990). According to J. L. Singer and D. G. Singer (1986), in a family household with a more imaginative, more creative and less aggressive home atmosphere, children watch less television during preschool years and consume television less as a source of free time activity and entertainment. Parents of these children establish rules related to television viewing, value imagination and creativity, and rarely resort to physical punishment. The Singers believe that television promotes and reinforces aggressive scripts. In order to deal with prohibition and social conflict situations, children need to enhance their verbal skills, play skills as well as fantasizing and imagination skills. These skills are developed in the best manner during early years of life via creative activities such as playing with parents and peers, reading, and story-telling by parents. However, children devote most of their time to television viewing instead of engaging in some creative activities (J. L. Singer and D. G. Singer, 1986). Television viewing can hamper education and steal from the time allocated to direct performance of activities to be successful in school (Murray, 1993). Educationalists are concerned that television viewing can take the place of reading and impair school performance (Gunter and McAleer, 1997). Also, Valkenburg (2001) reported that exposure to television violence led to anxiety and reduced the time of imaginative games children play. Sanders (1994), on the other hand, asserted that television portrayals affected children's imagination. He also stated that children were not engaged in imaginative activities, they did not need to make up new stories or create new games and all television studios were working for them.

According to researchers, form and content factors that attract children's attention are very important in determining the magnitude of effects the presentations will have (Huesmann and Taylor, 2006). Violence and aggression presented in form and content facilitate attention in children appear to include rapid movement, bright colors, and loud noises, traits that are often characteristic of violent scenes(Alvarez, Huston and Wright, 1988).Partly associated with the result brought about by imitated behaviours, observational learning leads to long-term effects of media violence. When young people imitate depicted behaviours, they identify themselves with the character by imagining the rewards and punishments other people receive (Bandura, 1986; Huesmann, 1997). Adoption of a behaviour portrayed on television becomes more likely when the model performs an exemplary or attractive behaviour, when the viewer identifies with the model, when the context is realistic and when the observed behaviour is rewarded (Bandura, 1977). In a global context,most media violence is rewarded and attractive media heroes often use violence to achieve their goals providing a three-fold message: (1) aggression is a good means to solve conflicts; (2) aggression offers status; (3) aggression can be fun (Groebel, 1998). When a screen hero uses violence as a means to reach success, viewers are affected and can resort to violence to settle their real-life conflicts (Giles, 2003). A television viewer is not directly rewarded for aggressive behavior observed in violent TV or movies, whereas a video game player is directly rewarded with points, auditory and visual effects, and progress through game levels (Gentile, Saleem and Anderson, 2007). If the violent content is rewarded and seen as "fun,' then aggression concepts will be classically conditioned with positive feelings. People can identify more with a character whom they perceive as identical, heroic and attractive (Heath, Bresolin and Rinaldi, 1989). Media characters become attractive role models especially when their violent actions are presented as justified and socially acceptable behaviours. Viewers identify more closely with realistic portrayals as they can more easily associate them with personal experiences (Geen, 2001). In video games with violent content, players can strongly identify themselves with the aggressor. Aggressive central characters are usually praised, glorified and portrayed as heroic. In recent years, the portrayal of aggressive characters 
in video games has become increasingly realistic (Gentile, Saleem and Anderson, 2007). Aggression is positively reinforcedwhen the television violence is commended, awarded or goes unpunished, and the aggressors are depicted as "good guys" or "super heroes". Viewers can be motivated to acquire the aggressive behaviour when the screen violence is portrayed as defensible, when there is no serious harm to the victim and when the violence is made to look funny (Strasburger, Wilson and Jordan, 2014). Violent scenes portrayed with no negative consequences are more likely to enhance viewers' aggression levels than violence scenes that have negative consequences such as remorse, great repentance, guilt, pain, suffering and sorrow (Comstock, 1985). Viewers watching the victim who experiences pain and suffering in violent media interactions may feel less aggression to a real person as the pain and suffering they feel can inhibit aggression (Baron, 1979). Television viewers observe that players resort to violence to achieve their goals and use it as a tool. Prolonged exposure to such media portrayals results in increased acceptance of violence as an appropriate means of solving problems and achieving one's goals (Hogan, 2005; Strasburger, Wilson and Jordan, 2014). Media tend to portray heroes using violence as a justified means of resolving conflict and prevailing over others. Television violence presented as" justified" is morelikely to elicitaggressive responses in the viewers(Hogben, 1998).

Children's perceiving and accepting violent media images as "just like it is seen in real life" motivated them to model and imitate violent and aggressive behaviour. Like portrayals, identification and realism is also associated with viewers. Relatively realistic portrayals aremore likely to increase viewers' aggressionthan those presented in a morefictionalized or imaginary fashion. Children who thought violent shows they watched were "just like the violence in real life" or who identified themselves with violent TV characters had higher physical and verbal aggression scores(Huesmann, Moise-Titus, Podolski et al., 2003). As emphasized before, researchers and theoristshave been discussing factors increasing the impact of media violence on children. Media themes that encourage the learning of aggression includes (a) "Good guys" or superheroes as perpetrators of violent acts; (b) violence that is celebrated or rewarded; (c) violence that goes unpunished; (d) violence that is portrayed as defensible; (e) violence that results in no serious harm to the victim; and ( $f$ ) violence that is made to look funny. On the other hand, media themes that are thought to discourage the learning of aggression are (a) evil or bad characters as perpetrators of violent acts; (b) violence that is criticized or penalized: (c) violence that is portrayed as unfair or morally unjust; (d) violence that causes obvious injury and pain to the victim; and (e) violence that results in sorrow and suffering for the victim's loved ones (Strasburger, Wilson and Jordan, 2014).

\section{Findings and Discussions Related to the Effects of Exposure to Media Violence on the Acquisition of Aggressive Behavior}

Researchers assert that short-term effects of exposure to media violence are due to processes including priming, excitation and immediate imitation of specific behaviours (Bushman and Huesmann, 2001; Huesmann, 1998). An external observed stimulus activates a brain node representing a cognition, emotion or behaviour (Berkowitz, 1993). When an individual is exposed to a violent act at a specific time, excitation spreads to other nodes and activates them. This process concerning the spreading activation in the brain's neural network is called priming. Exposure to media violence primes all sorts of nodes associated with aggression and increases the probability of aggression in the short run. In another important neural process, a child's observation of violence increases the risk of short-term aggressive behavior through mimicry (Huesmann, 2007; Huesmann and Kirwil, 2007). Many experiments have demonstrated that exposure to violent media increases children's and youth's likelihood of direct aggressive behaviour later (Bushman and Huesmann, 2001; Paik and Comstock, 1994). Bjorkqvist (1985) exposed 5- and 6-year-old Finnish children to either violent or nonviolent films. Children who had watched the violent film displayed significantly more physical aggression, such as hitting other children or wrestling, than those who had watched the nonviolent film.Josephson (1987) exposed that 7-9 year old boys who watched a violent film demonstrated more aggressive behaviour in a game of floor hockey they played at school. In another study conducted by Leyens and his colleagues (1975) at a school for juvenile delinquents in Belgium, there was an increased level of physical aggression among the boys who watched the violent films, than those who watched the nonviolent films. In another experimental 
study, male high school students witnessed an aggressive film depicting a prize fight. Then they delivered electric shocks to an experimental accomplice when provoked by another student and exposed to loud noise (Geen and O'Neal, 1969). Donnerstein and Berkowitz (1981) reported that males who had viewed a violent sex film punished the woman more intensely than did those who had watched either a neutral film or a non-violent sex movie. Researchers have examined the impact of violence on aggressive thoughts and emotions and shown that the risk of physically aggressive behavior against other people is increased among youth who believe that violence against others is acceptable (Huesmann \& Guerra, 1997), in part because they believe that their targets are "bad" people and that punishing them is justified.People who are at high risk for physical aggression against others were found to have an increased acceptance of physical aggression toward women (Lackie and de-Man, 1997), attributed hostile intent to others (Dodge and Frame, 1982), believed that taking revenge was "valuable" (Nisbett and Cohen, 1996) and fantasized about violence (Rosenfeld, Huesmann, Eron et al., 1982). Exposure to violence can directly increase aggressive thoughts in both children and older youth and thus make them more tolerant of aggressive behaviour. In another study, children who had watched a violent TV program were less ready to intervene and call an adult when a pair of preschool kids broke into a fight than were children who had seen a neutral film (Thomas and Drabman, 1975). Similarly, Malamuth and Check (1981) obtained findings showing that exposure to the sexually violent scenes increased the male subjects' acceptance of physical violence against women in the course of the next few days. Researchers have also conducted some studies to test the impact of violent video games on adolescents. In a research they conducted on 14-year-old Dutch male adolescents, Konijn, Bijnank and Bushman (2007)found that adolescents who played violent video games and who particularly identified with the video game character behaved more aggressively and delivered more intense and louder noise blasts that could cause permanent hearing loss in other boys than those who had played nonviolent games. A longitudinal study with elementary school students revealed that violent video game exposure early in the school year almost doubled the risk of children being involved in physical fights by later in the school year (Anderson, Gentile and Buckley, 2007). In a study of 607 adolescents conducted by Gentile and his colleagues (2004), students who were in the top quartile of aggressive or hostile personality trait doubled their risk of physical fights if they played a lot of violent video games, compared to high hostile students who did not play violent games. Whereas, the least hostile students (bottom quartile) were almost ten times more likely to get into fights if they played violent video games compared to other low hostile students who did not play violent games (Gentile, Lynch, Linder et al., 2004). In a study surveying electronic game-playing habits of fourth through eighth graders in elementary schools, it was found that two thirds of the children preferred violent games as their favorites (Funk, Flores, Buchman et al., 1999). Shibuya and Sakamoto (2003) stated that a great majority of the most popular video games played by Japanese fifth graders contained violent content. It has been reported that the rate of violence per minute is much higher in video games than in most violent TV programs or movies. In comparison to girls, boys are more attracted to and show a greater interest in violent media (Valkenburg and Janssen, 1999). However, males may be more strongly attracted to violent entertainment media than are females because media tend to cater to male audiences and use males as lead characters, such as "X-Men, Batman, Spiderman and Superman". It was found that although there was no gender difference in overall preference for violent video games, girls preferred fantasy violence, while boys preferred human violence (Funk and Buchman, 1996). Compared to females, males were more attracted to "justice restoring" violent programs, such as Batman; however, males and females were equally attracted to "comedic violence" (Cantor, 1998). Field and longitudinal studies also refer to the impact of media violence on viewers. In another field study conducted in Canada, the researchers found that both verbal and physical aggression significantly increased among children after the introduction of television in the Canadian town of Notel (Joy, Kimball and Zabrack, 1986). The relationship between television violence and aggressive behaviour has been documented in other nations as well. In a large-scale survey of more than 30,000 adolescents from 8 countries, Kuntsche and her colleagues (2006) established that heavy television viewing was significantly associated with increased verbal aggression and verbal bullying. In one of the earlier studies, Huesmann and his colleagues observed a group of children for a period of 22 years (Huesmann and Eron, 1986; 
Lefkowitz, Eron, Walder et al., 1977). The first study started in 1963 with sampling of 875 third graders ( 8 years of age) in New York. Their exposure to media violence at the age of 8 years correlated with their aggressive behaviour 11 and 22 years later, when potentially relevant factors including IQ, socioeconomic status, aggression displayed by parent as well as punishment and care used by parents were statistically controlled for. Findings revealed that repeated exposure to violence in early childhood was predictive of higher levels of aggression at age 19. The same group was surveyed 10 years later and the results revealed that there was a relationship between viewing TV violence at age 8 and selfreported aggression at age 30 among males (Huesmann and Miller, 1994). In a separate cross-cultural study, Huesmann and Eron (1986) observed more than 1,000 middle-class children aged 6 to 8 and 8 to 11 over a period of three years in Australia, Finland, Israel, Poland and the United States. For every country except Australia, early viewing of TV violence was significantly associated with higher subsequent aggressive behavior, even after controlling for a child's initial level of aggressiveness (Huesmann and Eron, 1986; Huesmann, Moise-Titus, Podolski et al., 2003). In a longitudinal study, Huesmann and his colleagues (2003) interviewed over 500primary school childrenat ages six to nine and surveyed them again 15 years later. Again, for both boys and girls, researchers found significant reciprocal relations between heavy exposure to media violence during childhood and a composite measure of physical, verbal and indirect violent behaviour in young adulthood (Huesmann, Moise-Titus, Podolski et al., 2003). Singer and Singer (1981) surveyed 141 children from nearly 50 different kindergartens for a period of one year. Researchers reported that children's viewing television violence was associated with their subsequent aggressive behaviour as observed during free play at school. In a subsequent study, Singer, Singer and Rapaczynski (1984) followed 63 boys and girls from age four to agenine. Again, they revealed that preschoolers who watched programs with most violent content displayed most aggressive behavior when they were nine years old. Ostrov and colleagues (2006) on the other hand, found that kindergarten children's violent media exposure was positively associated with the subsequent physical aggression among boys and with subsequent social and relational aggression among girls. In a large-scale study conducted inDunedin, NewZealand, Robertson and his colleagues (2013) determined 1037 individuals born in 1972-1973 and assessed them at regular intervals from birth to age 26. The results revealed that young adults who had spent more time watching television between the ages of 5 and 15 were likely to have more antisocial personality disorder, more criminal convictions, and more aggressive personality traits compared with those who viewed less television. In a survey of $7^{\text {th }}$ and $8^{\text {th }}$ graders in Germany, Krahe and Möller (2010) asserted that adolescents who selfreported more habitual media violence exposure displayed higher physical aggression and lower empathy. In another research, exposure of $3^{\text {rd }}, 4^{\text {th }}$ and $5^{\text {th }}$ grade children to violent media early in the school year predicted higher verbally aggressive behavior, higher relationally aggressive behavior, higher physically aggressive behavior, and less prosocial behavior later in the school year (Gentile, Coyne and Walsh, 2011).Non-delinquent high school students and juvenile delinquents who viewed media violence in childhood and adolescence were at an increased risk for development of violent behaviour and general aggression in adulthood (Boxer, Huesmann, Bushman et al., 2009). Meta-analyses also reported a positive, significant and consistent relationship between exposure to violent media and aggressive behaviour observed during all studies. Paik and Comstock (1994) reviewed 217 studies and found an overall effect size of 0.31 , which is considered medium in size.A large-scale meta-analysis by Bushman and Anderson (2001) examined 212 studies on the effects of media violence and also found that the effects of media violence on aggression have been increasing over time since 1975. Exposure to media violence increases the likelihood of aggressive thoughts, emotions, psychological arousal and subsequent aggressive or anti-social behaviour in viewers. Theoreticians and researchers maintain that repeated exposure to media violence gradually increasing in intensity is a risk factor playing a substantial role in developing aggressive behaviour over time.

\section{Conclusion}

Observational learning and imitating plays an important role for acquiring violent and aggressive behaviors throughout childhood and adolescence. Children can learn to behave aggressively in physical and verbal ways by observing and imitating the violent behaviors in the mass media. The laboratory and 
field experimentshave demonstrated that exposing children and youth to violent behaviors in films and on television increases the likelihood that they will behave aggressively immediately afterwards. Children can develop scripts for social problem solving, schemas about a hostile world, hostile attributional biases and normative beliefs approving of aggression through inferences they make from repeated observations of violent and aggressive behaviors on the mass media. The aggressive scripts, hostile attributional biases and normative beliefs increase the likelihood of children behaving aggressively. Children can establish well and easily retrieve from memory by imagining and rehearsing violent and aggressive behaviors on the mass media. Repeated exposures to violence on the mass media can lead to habituation of certain natural emotional reactions, or desensitization to later violence. Several other factors besides desensitization enhance the effects of media violence on children. Children can more identify with the observed models and encode in memory when they observe aggressive behaviors are rewarded and perceive the observed aggressive behaviors as just like it is in real life and justify using violence against the bad guys.

\section{Recommendations}

The trend toward increased amount and severity of aggression and violent on the media undermines the healthy development of the children in our contemporary world. The health and well-being of children and adolescents is at risk because they are exposed to media violence, including television, movies, computer games, and videotapes. Up until age seven or eight, children have great difficulty distinguishing fantasy from reality. Young children are particularly vulnerable to the negative and harmful influences for social, emotional, cognitive, and physical development during early childhood. Researches indicate that watching violent programs is related to less imaginative play and more imitative play in which the children simply mimic the aggressive acts observed on television (NIMH, 1982). The violent programs encourage children to imitate and reproduce in their play the behaviors seen on television or in movies. These situations undermine creative and imaginative plays of the children and thus children deprive of the benefits of necessary plays for their development (CarlssonPaige and Levin, 1990). In their play, children imitate those characters reinforced for their aggressive behaviors and repeat scripts of the characters without creative or reflective thought (Eron and Huesmann, 1987). Parents should take an active role in counteracting the potentially harmful effects of media violence on children. They ought use strategies that guide children interactions with television and prevent their children exposure to media violence. Parents establish the rules for household media use and the extent to which they use the media with their children. Parents should evaluate the shows together while they watch television and other media with their children. They can reduce the harmful effects of media violence on children via they talk to their children about media content and discuss what they see with their children. Parental efforts to interpret, elaborate, and provide supplemental information on violence presented by media have been found to be successful in countering negative or harmful effects of media violence on children. As noted earlier, researches have found that parents viewing and commenting on the programs together with the children reduce the effects of television violence on the children (Nathanson, 1999). Government or media industry must encourage positive media content and public education about the effects of media on children. Schools should teach media education because it may be useful in mitigating harmful effects of the media. Teachers have a responsibility to assist children in developing skills in nonviolent conflict resolution and support children to become critical viewers of media. They can improve critical viewing skills in the children and teach nonviolent strategies for resolving conflicts. Schools, the entertainment industry, or the government must protect children and adolescents from harmful media effects and maximize powerfully prosocial aspects on the modern media. The media industry and parents ought use the media constructively in order to expand the knowledge and develop the positive social values in the children. Parents should monitor television viewing habits of their children and protect their children from unhealthy exposure to media violence and the negative effects of viewing violent programs. 


\title{
Türkçe Sürümü
}

\begin{abstract}
Giriş
20. ve 21. yüzyılda yeni, etkileşimli iletişim teknolojilerinin ve kitle iletişim araçlarının artan varlığı sadece toplumda değil sosyal dünyada da köklü ve dikkat çekici bir değişme olarak görülmektedir. Televizyon, radyo, filmler, video oyunları, teyp kasetleri ve bilgisayar web siteleri gibi medya kaynakları çocukların ve ergenlerin yaşamlarında önemli roller oynamaktalar ve değerleri, inançları ve davranışları büyük ölçüde etkilemektedirler. Araştırma çalışmaları televizyondaki şiddeti izlemenin, saldırgan davranışın gelişimine bağımsız olarak katkı yapan faktörlerden biri olduğunu ortaya çıkarmaktadırlar. Medyadaki şiddete maruz kalma izleyicilerde saldırgan ve şiddet davranış riskini arttırmaktadır. Saldırganlık diğer bireye zarar vermek amacıyla doğrudan yapılan ve yöneltilen belirli bir davranış olarak tanımlanmaktadır. Saldırgan kişi saldırgan davranışın hedefteki bireye zarar vereceğine ve onun böyle saldırgan davranışlardan kaçınmak için motive olduğuna inanmaktadır (Anderson ve Bushman, 2002b; Berkowitz, 1993; Geen, 2001; Swing ve Anderson, 2010). Saldırgan davranış her zaman fiziksel biçimde ve özellikte olmamaktadır. Psikologlar sözle intikam alma, misilleme yapma, dedikodular yaymayla meşgul olma ya da insanlara hakaret etme ya da küfür gibi saldırganlığın daha hafif biçimlerini ayırt etmektedirler (Ostrow ve Godleski, 2010). ílişkisel ya da sosyal saldırganlık bir kişiye fiziksel olarak zarar vermekten çok duygusal olarak acı çektirmeyi amaçlamaktadır. Sosyal saldırganlık erkek çocuklarla karşılaştırıldığında kız çocukları arasında daha çok gözlemlenmektedir (Spieker, Campbell, Vandergrift ve diğerleri, 2012). Medyadaki şiddet, bir kişinin diğerine zarar vererek yaptığı fiziksel saldırganlığın görsel betimlemeleri olarak tanımlanmakta ve medyadaki öykü karakterleri yoluyla betimlenen saldırgan ve şiddet davranışlarına işaret etmektedir. Bu karakterler insan ya da insan olmayan, çizgi filimsi (cartoonish) ya da görsel olarak gerçeğe uygun olabilmekteler, gerçekçi olmayan, kurgusal, hayali, ya da canlı ya da gerçekçi şiddet olarak ortaya çıkmaktadırlar (Huesmann ve Taylor, 2006; Gentile, Saleem ve Anderson, 2007; Swing ve Anderson, 2010). 2000'den daha fazla bilimsel araştırmaların ve yeniden incelemelerin sonuçları medyadaki şiddete alışkanlıkla daha çok maruz kalmanın belirli çocuklarda ve ergenlerde saldırgan davranış riskini arttırdığını, onları şiddete duyarsızlaştırdığını ve dünyanın içinde yaşamak için "daha acımasız ve daha korkutucu" bir yer olduğuna inandırdığını göstermişlerdir (Strasburger, Wilson ve Jordan, 2014).
\end{abstract}

Ailede televizyonu izleme sıklığı ya da boş zamanda televizyonu seyretme sıklığı, çocukların televizyonda betimlenen şiddete maruz kalma derecesini etkilemektedir. Çocuklar ve 13-19 yaş arası gençler uyuma dışında meşgul oldukları belirli bir etkinliklerle karşılaştırıldığında çeşitli medya ile daha çok zaman geçirmektedirler (American Academy of Pediatrics, 2010). Genç insanlar bir günde çeşitli farklı medyayı kullanmaya 7 saatten daha çok zaman ayırmaktadırlar. 8-18 yaşlarında 2000'den daha çok birey üzerinde Kaiser Aile Kuruluşunun yürüttüğü bir araştırma (2010) Amerika Birleşik Devletlerinde çocukların ve gençlerin medyayla bir günde ortalama 7 saatten daha fazla zaman geçirdiğini ortaya çıkarmaktadır (Rideout, Foehr ve Roberts, 2010). Amerika Birleşik Devletleri ulusal raporuna göre yaklaşık çocukların üçte ikisi ve 2 yaşından küçük bebekler bir günde 30-60 dakika televizyon izlemeye maruz bırakılmaktadır. Medya ile zaman geçirme yaratıcı, aktif ve sosyal etkinliklerle meşgul olmanın yerini almaktadır (Vandewater, Rideout, Wartella ve diğerleri, 2007). Okul öncesi ana sınıfı çocukları okuma, yeni şeyler öğrenme ve dışarıda oyunlar oynama ile karşılaştırıldığında televizyondaki gösterilerieğlenceleri izlemeye çok daha fazla zaman harcamaktadırlar (Rideout, Vandewater ve Wartella, 2003). Okul öncesi çocukları ve okul-çağı çocukları, bir günde 2-4 saat televizyon seyretmekteler ve bu en çok izlenen akşam programlarında her bir saatte 5 şiddet eylemi betimlenmektedir. Çocukların cumartesi sabah programları bir saatlik sürede ortalama 20-25 şiddet eyleminin betimlendiği en yüksek şiddet oranına sahiptirler. Komedi programları, müzik videoları ve gerçek, realite gösterileri ile karşılaştırıldığında çocukların programları daha yüksek bir sıklıkta şiddete sahiptirler (Gentile, Saleem ve Anderson, 2007). 2570 insan üzerinde Radyo Televizyon Üst Kurulu (RTÜK) tarafından yürütülen bir 
araştırma günlük televizyon izleme sıklığının yetişkinler ve çocuklar için ortalama 4 saatin üzerinde olduğunu ortaya çıkarmıştır (RTÜK, Televizyon İzleme Eğilimleri Üzerine Bir Araştırma-2, 2009). Şiddetin düzeyleri üzerine diğer bir araştırmada hafta içi 16.00-21.30 ve hafta sonu 09.00-21.30 saatleri süresince incelenen Türkiye'de beş özel televizyon kanalında gösterilen 80 filmden, toplam 5600 saniyesinde şiddetin oranının \% 33,1 olduğu bulunmuştur (Ayrancı, Köşgeroğlu, Günay, 2004). Araştırma medyadaki şiddetin yaygınlığını ve şiddetin televizyonda betimlenme biçimlerini de vurgulamıştır. Televizyon programlarının \% 60'ı şiddeti içermekte iken (Wilson, Kunkel, Linz ve diğerleri, 1998), şiddet video oyunlarının \% 90'ında betimlenmektedir (Children Now, 2001). Televizyondaki şiddet sıkıkla seyirciler için çekici hale getirilmekte ve tüm şiddet programlarının \% 96'sı saldırganlığı seyircileri sadece eğlendirme amacında öykü türünden sinemaya özgü bir araç olarak kullanmaktadır. Şiddet etkileşimlerinin \% 44'ü taklidi teşvik etmek için belirli değerli çekici niteliklere sahip olan saldırgan bireylerle yapılmıştır.Saldırgan davranış sergileyenlerin \% 40' genç seyirciler için rol modeller olarak hizmet eden ve "iyi" karakterlere ya da karakteristiklere sahip olan insanlardır. Böylece televizyondaki şiddet izleyiciler için çekici yapılmaktadır. Şiddet sahnelerinin \% 71'i şiddet davranışlarını sergileyen kişi için üzüntü, pişmanlık, eleştiri ya da ceza betimlememiş ve \% 86 'sı kanlı yaralamayı ya da boynuzla vurmayı gösteren sahneleri içermemiştir. Televizyondaki şiddet eylemlerinin yaklaşık bir yarısı kurbanı zarara uğratmamış ya da kurbanda belirli acıya neden olmamış ve şiddet programlarııı sadece \% $16^{\prime}$ sı kurban ya da kurbanın ailesi ile ilişkili olan uzun-süreli olumsuz etkileri yansıtmıştır. Şiddet sahnelerinin yarısından daha çoğu şiddeti önemsizleştirerek gerçek-yaşamda öldürücü olabilen fiziksel şiddeti içermiş ve yaklaşık \% 40'ı ya doğrudan şiddeti betimlemiş ya da şiddeti yapan karakterleri kullanmıştır. Oysa \% $75^{\prime} i$ şiddete karışan kişiye ceza veren ya da suçlu bulan sahnelere öncelik vermiştir. Hemen hemen tüm programların \% 45'i yaptığı saldırgan eylemlerinden dolayı hiç cezalandırılmayan ya da seyrek cezalandırılan "kötü" karakterleri içermiş̧ir. Şiddet sahnelerinin \% 40'ı bazı güldürü ve eğlendirme biçimlerini içermiş ve sadece $\% 5^{\prime}$ den daha azı şiddete-karşı mesajları vermiştir. Televizyonda ana öykülerde tüm şiddet çekici ve değer verilir bir şey olarak betimlenmiştir. Televizyonda, filmlerde ve video oyunlarında saldırganlık sözde iyi nedenlerle kötü insanlara verilmiş bir ceza biçimi olarak kullanılmıştır. Şiddet eylemlerinin \% 44'ü "hakı”" olarak betimlenebilir bir tutumda sunulmuştur (Wilson, Kunkel, Linz ve diğerleri, 1998). Televizyondaki şiddet özellikle çocukları hedef almıştır. Çocukları hedef almayan gösterilerin \% 57'si şiddeti içermişken, çocuklara yönelik gösterilerinin yaklaşık \% 70'i tamamen şiddet içerikli olmuştur. Şiddet eylemlerini gösteren insanların \% 36'sı çekici kişilik özelliklerine sahip olmuştur. Şiddetin \% 30'u "haklı" olarak tanımlanmış ve şiddet sahnelerinin \% 81'i saldırganlar için belirli bir cezayı betimlememiştir (Wilson, Smith, Potter ve diğerleri, 2002).Şiddet sahnelerinin \% 34'ünde kurbana verilen zarar gerçekçi olmayan bir biçimde betimlenmiştir. Gerçekçi olmayan zarar, çizgi filmlerindeki (cartoons) durumda olduğu gibi en çok çocukların programlarında görülmüştür (Wilson, Kunkel, Linz ve diğerleri, 2002, 1998). Şiddet içeriğinin bir başka çözümlemesi bazı saldırganlık biçimlerinin 5. sınıf kız öğrencileri arasında popüler olmuş televizyon programlarının çoğunda (\% 88) betimlendiğini ortaya çıkarmışır. Programların \% 77 si dolaylı saldırganlığı betimlemiş, \% 71'i fiziksel saldırganlı̆̆ı içermiş ve \% 69'u sözlü saldırganlığı kapsamıştır. Diğer yandan, bütün eylemlerin \% 60'ı fiziksel saldırganlık olarak, \% 23'ü dolaylı saldırganlık olarak ve \% 17'si sözlü saldırganlık olarak betimlenmiştir. Bu noktada, saat başına 10 fiziksel saldırganlık gözlenmiştir. 6 şiddet eyleminin betimlendiği diğer programlarla karşılaştııılığında, çocukları hedef alan programların tipik bir saati 14 farklı şiddet eylemini içermiştir. Çocukların programlarında şiddet çizgi filmlerindeki gibi daha güldürücü bir tutumda betimlenmiştir (Linder ve Lyle, 2011). 2-11 yaş arasında çocuklarda en çok-izlenen 50 programın bir içerik çözümlemesinde sosyal saldırganlığın oldukça yaygın olduğu ve gösterilerin \% 92'sinin sosyal saldırganlığı içerdiği gösterilmiştir. Tüm diğer programlar saat başına 4 şiddet eylemi içermişken, çocukların programlarında 14 farklı şiddet eylemi betimlenmiştir (Martins ve Wilson, 2012a). Şiddet rolleri çocukların programlarında eğlence olarak daha çok betimlenmiştir. Çocukları hedef alan programların çoğu çizgi filmlerini canlandırmışır (Strasburger ve Wilson, 2014).

\section{Çalışmanın Amacı ve Önemi}

Var olan makale sadece deneysel ve alan araştırmalarına değil, çocuklukta medyadaki şiddeti izlemenin daha sonraki yıllarda saldırgan davranış üzerindeki etkilerini açıklamaya çalışan teorilere değinmeyi 
amaçlamaktadır. Çocuklukta medyadaki şiddete daha sık ve yoğun olarak maruz kalma ile daha sonraki yıllarda saldırgan davranışı gösterme arasındaki ilişkiler teorik bir arkaplan olarak gözlemsel öğrenme ve taklit etme çerçevesinde ve deneysel ve alan araştırmaları temelinde tartışılmaktadır. Günümüz toplumunda şiddetin ve saldırgan davranışın yaygınlaşması bir sosyal sorun olarak varlığını sürdürmektedir. Medyadaki şiddeti izlemenin daha sonraki yıllarda şiddet ve saldırgan davranışlara katkısı teorik görüşler kadar deneysel ve boylamsal araştırmalar temelinde ortaya çıkarıldığında, şiddet ve saldırgan davranışların altında yatan nedenlerin bir bölümü belirli bir ölçüde anlaşılabilmektedir. Medyadaki şiddete maruz kalmanın zararlı etkilerinin bir sonucu olarak izleyicilerde gelişen şiddet ve saldırgan davranışların temelinde yatan nedenler ve mekanizmalar bilindiğinde, hükümetler, politikacılar, medya endüstrisi, okullar ve aileler çocukları medyadaki şiddetin zararlı etkilerinden korumayı amaçlayan belirli girişimlerde bulunarak bu soruna çözümler üretebilmektedirler.

\section{İncelenen Araştırmalardaki Yöntem, Veri Toplama Teknikleri Ve Araştırma Süreçleri}

$\mathrm{Bu}$ çalışmada medyada ve filmlerde şiddet ve saldırganlık davranışlarını izlemenin çocuklarda ve gençlerde saldırganlık davranışlara kısa süreli etkileri kadar çocuklukta televizyondaki şiddete daha çok maruz kalmanın daha sonraki çocukluktaki, ergenlikteki ve ortaya çıkan yetişkinlikteki saldırgan davranışlara etkisi ile ilgili deneysel araştırma çalışmalarını ele alan boylamsal araştırma tanıtılmakta ve betimlenmektedir. Deneysel araştırmada veri şiddeti seyreden ve seyretmeyen çocuklar bir odada birlikte oynadıklarında vurma, güreşme, mücadele etme gibi fiziksel saldırganlık davranışları (Bjorkqvist, 1985) ya da bir salon hokeyi oyununda vurma, çelme takma, diz ile vurma, dirsekle vurma, saçı çekme, hakaret etme, aşağılama gibi saldırganlık davranışları gözlemleyerek elde edilmektedir (Josephson, 1987). Çocuklardaki saldırgan davranışlar ailelere televizyonun girişi öncesi ve sonrası dönemler karşılaştırılarak gözlemlenmiştir (Joy, Kimball ve Zabrack, 1986). Boylamsal araştırmalar 6-11 yaş arası okul çocukları ve onların anneleri-babaları ile görüşmeleri içermiş ve Saldırganlığın Akran-Değerlendirme Göstergesi olarak adlandırılan çocukların saldırgan akranları bildirdiği bir ölçek çerçevesinde her bir çocuk bir sınıf çevresinde "hiçbir şey yokken kavga-dövüş başlatma" ve "diğer çocukları itme ve kakma" gibi 10 saldırgan davranışla meşgul olan akranlarını bildirmiştir. Şiddeti izleme sıklığı ile ilişkili olan veriler çocuklara fiziksel şiddetli ve şiddetsiz televizyon programının bir listesi sunularak ve "bütün zaman" "bazen fakat bütün zaman değil" ya da "arada bir" seyrettikleri programları işaretlemesi için onlara sorular sorarak elde edilmiştir (Huesmann ve Eron, 1986). "The Bionic Woman" ve "The Six Million Dollar Man" gibi iki saldırgan erkek ve iki saldırgan kadın sunularak, çocuklara onların çeşitli yetişkin saldırgan özelliklerini ne kadar sevdikleri ya da ne kadar onlar gibi davrandıkları sorulmuştur. Çocukların televizyondaki saldırgan davranış ile kendilerini özdeşleştirmeleri ile ilişkili olan veriler "2= çok, 1=biraz, $0=$ hiç değil” gibi farklı cevaplar alarak toplanmıştır (Huesmann ve Eron, 1986). Çocuklardan onların karar verdikleri çeşitli şiddet programlarının ne kadar gerçekçi olduğunu değerlendirmeleri istenmiştir. Değerlendirme ölçeği aşağıdaki gibidir: "3=gerçek yaşamda olduğu gibi haklı, 2= gerçek yaşamda olduğu gibi biraz ve gerçek yaşamda olduğu gibi hiçte değil”. Çocukların televizyon izleme alışkanlıklarını etkilediği varsayılan entelektüel yetenek ile ilişkili olan veriler okul kayıtlarından elde edilmiştir. Çocukluktaki entelektüel yeteneği değerlendirmek için Kaliforniya Başarı Testi (Tiegs ve Clark, 1970) tüm üçüncü sınıf öğrencilerine uygulanmış ve "The Oak Pak Okumaya Hazırlık Testi"i birinci ve ikinci sınıf öğrencileri için kullanılmıştır. Warner, Meeker ve Eells'in Sosyo-Ekonomik Statü (SES) Ölçeği (1960) annelerin-babaların sosyo-ekonomik statü ve eğitim düzeyleri hakkında sağladıkları bilgiye dayanan anne-baba değişkeni ile ilişkili olan verileri toplamak için kullanılmıştır. Annelerin-babaların saldırgan davranışları Minnesota Çoklu Aşamalı Kişilik Envanteri (Huesmann, Lefkowitz ve Eron, 1978) kullanılarak değerlendirilmiş ve saldırgan davranışlar annelerin-babaların son yılda kaç kez (1) diğer bir yetişkini boğduğu, yumruk attığı ya da dövdüğü, (2) diğer bir yetişkine tokat attığı ya da tekme attığı ya da (3) birini bir bıçakla tehdit ettiği ya da gerçekten yaraladığı ya da birini bir silahla tehdit ettiği ya da vurduğu ile ilgili üç maddeyle ölçülmüştür (Huesmann, Eron, Lefkowitz ve diğerleri, 1984). Saldırganlığı hayal etme, çocukların hayal etme envanteri ile ilgili saldırganlık ölçeğinin yetişkin versiyonu ile değerlendirilmiştir (Rosenfeld, Huesmann, Eron ve diğerleri, 1982). Çocuk yetiştirme yöntemleri ve tutumları, (1) çocuğun reddedilmesi, (2) çocuğun yetiştirilmesi, (3) çocuğun sert cezalandırılması, (4) hareketlilik yönelimi örneğin başarılı olma isteği gibi ölçütler kullanılarak değerlendirilirken, annelerin- 
babaların televizyon izleme sıklığı, annnelerin-babaların kendileri ile görüşmeleri sürdürme, seyrettikleri programları bildirmesi ve bu programları değerlendirmesi ile belirlenmiştir (Huesmann ve Eron, 1986). Boylamsal araştırmalar çocukluğu ve yetişkinliği karşılaştırmayı gerektirdiği için, aynı katılımcıların her iki dönemine ilişkin veriler toplanmıştır. Araştırmayı tamamlamak için kayıtlar takip edilerek erkek ve kız çocukların çoğu ile iletişime geçilmiştir. Ayrıca, bu bireylerle, onların eşleriyle ve arkadaşlarıyla görüşülmüş ve belirli veriler devlet arşivlerinden elde edilmiştir. 6-11 yaşlar arasındaki döneme ait verilerine sahip çocuklar büyüdüğünde ve $20^{\prime}$ li yaşlara ulaştığında tekrar kişisel olarak ya da telefonla iletişime geçilmiş, yetişkinlikteki saldırgan davranışa ilişkin olan veriler üç farklı kaynaktan, yani, kendilerinin-verdiği bilgilerden, diğer kişilerden ve devlet arşivlerinden toplanmıştır. Düzenli olarak ya da sıklıkla seyrettikleri üç favori televizyon programları hakkındaki kendilerinin-verdiği bilgilere dayanarak, şiddeti izleme sıklığı, 0'dan (=görünür şiddet yok ya da görünmemesi zayıf ya da ifade edilen şiddet) 4'e (=yüksek görünür şiddet) kadar sıralanan bir değerlendirme şeması yoluyla belirlenmiştir. Dolaylı, sözlü ve hafif fiziksel saldırganlık "onlar diğer bir kişi ile çatıştığında ya da kızdığında" katılımcıların meşgul olduğu çeşitli davranışlar hakkında kendilerinin-verdiği bilgiler yoluyla değerlendirilmiştir. Dolaylı saldırganlık katılımcıların "diğer kişinin eşyalarını alma" ve "onları sevmeyen diğer insanlara vurmaya çalışma" gibi davranışlarla ne kadar sıklıkla meşgul oldukları hakkında kendilerinin-verdiği bilgiler yoluyla ölçülmüş ve sözlü saldırganlık onların "diğer kişiye ad takarak çağırma” diğer kişinin fiziksel yeteneklerini ve görünümünü küçümseme ve aşağılama" gibi davranışları ne kadar gösterdikleri hakkında kendilerininverdiği bilgiler yoluyla belirlenmiştir. Diğer yandan, hafif fiziksel saldırganlık katılımcılardan "onların ne kadar sıklıkla diğerlerine vurdukları, tekme attıkları ve itip kaktıkları" gibi 3 maddeden oluşan bir soruya cevap vermelerini gerektiren kendi-raporları yoluyla ölçülmüştür (Bjorkqvist, Osterman ve Kaukianen, 1992). Genel Saldırganlık Ölçeği çocuklar için orijinal akran-aday gösterme ölçeğine dayanan 12 maddeyi içermiş ve yetişkinler için uyarlanmış ve yeniden yazılmıştır. O "Ne kadar sıklıkla diğerlerine parmak sallarsınız?" "Ne kadar sıklıkla hiçbir şey yok iken kavgayı başlatırsınız?" ve "Ne kadar sıklıkla sormadan insanların eşyalarını alırsınız?" gibi böyle soruları içermiştir. Bu sıklık ölçülerinin tümü için cevap ölçeği "0=asla değil"den "4=çok sık sık"a kadar sıralanmıştır (Huesmann ve Eron, 1986). Sert fiziksel saldırganlık son yılda katılımcıların kaç kez "diğer bir yetişkini boğduğu, yumruk atttığı ya da dövdüğü", "diğer bir yetişkine tokat attığı ya da tekme attığı" ya da birini bir bıçakla tehdit ettiği ya da gerçekten yaraladığı ya da birini bir silahla tehdit ettiği ya da vurduğu" ile ilgili üç maddeyi içermiştir (Huesmann, Eron, Lefkowitz ve diğerleri, 1984). Straus'un Çatışma Taktikleri Ölçeği (Straus, Gelles ve Steinmetz, 1980) kullanılarak, katılımcılardan ne kadar sıklıkla eşlerine (ya da önemli diğerine) karşı saldırdığını (Straus, Gelles ve Steinmetz, 1980) bildirmeleri istenmiş ve onların anti-sosyal/saldırgan kişilik özellikleri değerlendirilmiştir (Huesmann, Lefkowitz ve Eron, 1978). Konuyla ilgili çeşitli sorular katılımcılara yöneltilmiş ve onlardan onların trafik ihlallerini ve belirli farklı suç türlerini işleme sıklığını ve onların tutuklanıp tutuklanmadığını ya da suçlu bulunup bulunmadığını bildirmeleri istenmiştir.

\section{Saldırgan Davranışları Kazanmayı Sosyal Öğrenme Teorisi Temelinde Açıklama}

Medyadaki şiddeti izlemenin saldırganlık davranışları üzerindeki etkisi gözlemsel öğrenme ve taklit etme temelinde bir teorik çerçeve içinde tanımlanmıştır. Sosyal öğrenme ya da gözlemsel öğrenme ve taklit etme saldırganlık gibi sosyal davranışları kazanmada önemli bir rol oynamakta; ayrıca, öğrenme süreci daha güçlü olmakta ve insanlar diğerlerini gözlemleyerek ya da taklit ederek saldırgan biçimde davranmayı öğrenmektedirler (Bandura, 1977). Çocuklar oyun alanında anneleri-babaları, akranları ve daha büyük kardeşleri gibi birçok kaynakla sosyal etkileşimlere girmekteler, televizyondaki ve filmlerdeki kurgusal karakterleri gözlemlemekteler ve sonra bu davranışların kendilerini sergilemektedirler (Bandura, 2001). İnsanların gözlemlediklerini taklit etmek için içsel bir eğilime ve önceden-tasarlanan belirli sinir sistemlerine sahip olduğu ve bu sinir sistemlerinin taklit ederek öğrenmek için özel bir fizyolojik sistemi içerdiği bilinmektedir (Rizzolatti ve Craighero, 2004; Rizzolati, Fadiga, Gallese ve diğerleri, 1996). Gözlemci (a) model davranışa dikkat etmekte ve bakmakta, (b) sembolik olarak model davranışı bellekte tutmakta ve görsel ya da sözlü olarak onu kodlamakta, (c) davranışın aynısını yapmakta ve (d) yaptığı davranışın sonuçlarına değer vermektedir (Bandura, 1977). Davranış modelleri sembolik bir tutumda bellekte tutulmaktadırlar. Gözlemsel öğrenme hayal etmeye ve kendini ifade etmeye dayanmaktadır. Davranışlar, hayal edilerek bellekte tutulmaktadırlar. Duyuların uyarılması, dışsal 
olayların algılanmasına yol açmaktadır. Tekrar tekrar maruz kalmanın bir sonucu olarak uyarıcı, model performansın sürekli, kazanılabilir görüntülerini yansıtmakta (Bandura, 1986), böylece modellerin görüntüleri fiziksel varlıklarının yokluğunda toparlanabilmekte ve gösterilebilmektedir. Tekrar tekrar gözlemlenen bir etkinliğe dayanarak modelin hayali bir kopyası yaratılabilmektedir (Liebert ve Spiegler, 1990). Görsel canlandırma, hayalinde canlandırma, ifade edilen becerilerinin yokluğunda gözlemsel öğrenmenin ilk aşamasında önemli bir rol oynamaktadır. Bilişsel içerikler görsel olmaktan çok genellikle ifade etmeye dayanmaktadır. Gözlemlenen bir davranışın ayrıntıları, görsel bilginin sözel kodlara ya da ifadelere dönüşümü yoluyla kazanılmakta, bellekte tutulmakta ve daha sonra performans sergilenmektedir (Bandura, 2001). Gözlemsel öğrenme ve bilgiyi bellekte tutma bilginin çoğunu orijinal olarak depolanan biçimde taşımaları nedeniyle sembolik kodlarla daha kolay yapılmaktadır. Model alınan etkinlikler hemen kullanılabilen ifadenin görüntülerine ve sözlü sembollerine dönüştürülmekte ve bu bellek kodları performans için yol göstericiler olarak hizmet etmektedirler (Liebert ve Spiegler, 1990). Sembolik kodlamaya ek olarak tekrarlama ya da prova yapma da önemli bir bellek desteği olarak hizmet etmektedir. Gördükleri şeyi düşünmeyenlerle ya da uygulamayanlarla karşılaştırıldığında insanlar, model aldıkları davranışları zihinlerinde tekrarladıklarında, prova yaptıklarında ya da gerçekten yaptıklarında, onlar daha az unutmaktadırlar (Bandura, 1997).

Bandura taklit etmenin sosyal öğrenme için anahtar olduğunu tartışmaktadır. O bireylerin gördükleri belirli sosyal davranışları taklit etme ile birlikte gözlemlere dayanan bilişsel çıkarımlar yaptıklarını ve bu çıkarımsal yargıların davranışlarda genelleştirmelere yol açıı̆ını da bildirmektedir. Çocukların gözlemledikleri eylemleri yaptıklarında olayları nasıl yorumladıkları ve nasıl hissettikleri önem kazanmaktadır (Bandura, 1986). Bir annenin-babanın diğer bir anneye-babaya vurduğunu gözlemleme sadece bir çocuğun diğerine vurma olasılığını değil aynı zamanda bir kişi sizi provoke ettiğinde vurmanın kabul edilebilir olduğu inancını da arttırmaktadır (Bushman ve Huesmann, 2010). Çocuklar gözlemledikleri davranışlardan çıkarımlar yapmaktalar ve belirli davranışların uygunluğu hakkında inançlar geliştirmektedirler. Çocuklar bir bireyin saldırgan biçimde davranarak bir sosyal problemi çözdügünü gördüklerinde, onlar saldırganlıkla ilgili bir senaryoyu zihinlerinde yaratmaktalar ve tutmaktalar ve böyle davranışların kabul edilebilir olduğuna ilişkin bir inancı geliştirmektedirler. Daha sonra senaryoyu kullanmaya karar verdiklerinde, onlar onu yeniden bulup getirmekteler ve çoğunlukla benzer tutumda davranabilmektedirler (Guerra, Huesmann ve Spindler, 2003; Huesmann ve Kirwil, 2007). Huesmann (1988) saldırgan davranış çözümlemesinde bilişsel şema ile ilişkili kavramlar olarak senaryolara dikkat çekmiş ve saldırgan davranışın entelektüel davranış için olan senaryolar gibi aynı biçimde çoğunlukla kodlanan, tekrarlanan, depolanan, tutulan ve hatırlanan senaryolarla büyük bir ölçüde kontrol edildiğini tartışmışır. Çocuklar belirli davranışları ve çatışma gibi çeşitli durumları yorumlamak, anlamak ve üstesinden gelmek için bir dizi kurallar olarak modellerden daha çok genelleştirmeyi ve karmaşık sosyal senaryoları öğrenmektedirler (Huesmann, 1998). Öğrenildiğinde, böyle senaryolar gelecekteki davranışlar için bir bilişsel bir tahmin edici olarak işlev görmektedirler. Örneğin, çocuklar şiddet davranışı sergileyen insanları gözlemleyerek saldırganlığın kişiler arası çatışmaları çözmeye çalışmak için kullanılabildiğini öğrenmektedirler. Bu tür davranışı hayal etme gibi zihinsel tekrarlamaların ya da şiddete çok maruz kalmanın bir sonucu olarak bu çatışmayı çözme yönündeki bir tutum bellekte tutulmakta ve sonra kolayca yeniden edinilmektedir. Özellikle çevredeki şiddeti gözlemleme çocukların dünya şemalarıı etkilemekte ve onların diğerlerinin eylemlerini düşmanca olarak algılamasına neden olmaktadır (Gerbner, Gross, Morgan ve diğerleri, 1994). Dodge ve meslektaşlarına (1995) göre tekrar tekrar gözlemlemelerden yapılan çıkarımlar çocukların dünya hakkında düşmanca ya da olumlu yargıları kadar kabul edilebilir davranış türleri ile ilişkili olan inançlar geliştirdiğini ortaya koymaktadır. Şiddetin sık gözlemlenmesi çocukların dünya şemalarını "düşmanlık" ile ilgili olarak etkilemektedir. Onlar diğerlerinin eylemlerini düşmanca olarak düşünmekteler ve böyle düşünmeler çocukların daha sonraki yıllarda şiddet davranışlarının olasılığını arttırmaktadırlar. Benzer olarak, Huesmann ve Guerra (1997) hem gerçek yaşamdaki hem medyadaki şiddet rol modellerinin tekrar tekrar gözlemlenmesinin çocukların saldırganlığın uygunluğu konusunda normatif inançlar geliştirmesi ve saldırgan biçimde davranması yönünde sosyal senaryolar edinmesi için motive ettiğini vurgulamıştır. Normatif inançlar, gözlemleme, deneyim ve doğrudan öğretim yoluyla kazanılan bilginin bilişsel soyutlamaları olarak görülmekte ve bir davranışın kabul edilebilirliği ya da kabul edilemezliği 
hakkında bireylerin kendi bilişlerini ya da bilişsel standartlarını ifade etmektedir. İnançlar duruma özel ya da genel olabilmektedirler. "Eğer onlar sana ilk olarak vurur ise diğerlerine vurmak uygundur" bir duruma-özel normatif inanç örneği olabilmekte, oysa "diğerlerine vurmak uygundur" genel bir inancı yansıtmaktadır. Çocuklar yetişkinliğe doğru büyüdükçe, çevrelerindeki dünya hakkındaki sosyal-bilişsel şemaları onlara daha ayrıntılı olmaya başlamakta, hangi sosyal davranışların uygun olduğu ile ilgili normatif inançlar daha belirgin olmakta ve bu inançlar uygun olmayan sosyal davranışları sınırlamak için süzgeçler olarak harekete geçmeye başlamaktadırlar. Ailelerin, akranların, sosyal grupların ve kitle iletişim araçlarının gözlemlenmesi yoluyla kazanılan sosyal senaryolar uygulamada daha karmaşık ve otomatik olmaktadır (Huesmann ve Guerra, 1997). Crick ve Dodge'un (1994) dikkat çektiği gibi, cevap verme bir davranışın kabul edilebilirliği hakkındaki inançlarla ilişkili olan ahlaki standartlarla ve değerlerle yönetilmektedir. Saldırganlı̆̆ı daha çok onaylayan normatif inançlara sahip insanlar daha saldırgan olabilmektedirler. Sadece saldırganlığı onaylayan normatif inançlar değil aynı zamanda gerçek saldırgan davranış da ilkokul yılları boyunca yaşla birlikte artmaktadırlar (Huesmann ve Guerra, 1997).

Medyadaki şiddete maruz kalmanın saldırganlık davranışı üzerindeki uzun-süreli etkilerini tanımlayan diğer bir yaklaşım duyarsızlaşma teorisi olarak adlandırımaktadır. Yeni araştırma medyadaki şiddete maruz kalma ile duyarsızlaşma arasındaki bir ilişkiyi belirlemiştir (Bailey, West ve Anderson, 2011). Medyaya ve video oyunları gibi duygusal uyarıcılara tekrar tekrar maruz kalma belirli doğal duygusal tepkilere alışmaya ya da "duyarsızlaşmaya" yol açabilmektedir. Acı verici sonuçları ile kanlı yaralanmaların, boynuzla vurmanın ya da diğer sahnelerin saldırganlığı engelleyebileceği beklentilerine karşın, araştırma böyle sahnelerin izleyicilerin bazılarında saldırganlığı arttırabildiğini ortaya çıkarmaktadır. Böyle olumsuz sonuçlara tekrar tekrar maruz kalma bireyleri kanlı yaralanmalara, boynuzla vurmaya ve kurbana acı vermeye neden olan diğer sahnelere ve görüntülere duyarsızlaştırabilmektedir. İlk önce alışılmamış bir biçimde gözlemlenen davranışlar onları tekrar tekrar izledikten sonra çocuklara normatif görünmeye başlamaktadırlar. Çocukların, belirli bir sahneye bir tepki olarak hissettiği duygular bu belirli sahneye tekrar tekrar maruz kaldıktan sonra yoğunlukta azalma eğilimindedirler. Kanı, boynuzla yaralanmayı, boynuz vurmayı ve şiddeti gözlemlediğinde birçok insanın doğuştan olumsuz bir tepkiye sahip olduğu görünmektedir. Artan kalp atış hızı, terleme ve rahatsızlık böyle maruz kalmayla birlikte olabilmektedir. Şiddeti tekrar tekrar gözlemleme ve maruz kalmayla, böyle olumsuz duygusal tepkilere alışılmakta ve çocuklar duyarsız duruma gelmektedir. Böyle bir alışma, medyadaki saldırganlığın doğal sonuçları için cezalandırmayı etkili olarak yok edebilmektedir. Çocuklar, daha sonra böyle olumsuz duyguları yaşamaksızın saldırgan bir tepkiyi düşünebilmekteler ve gösterebilmektedirler. Sonuç olarak, saldırganlık daha olası olmaktadır. Deneysel olarak, olumsuz duygusal tepkileri daha güçlü biçimde verenlerle karşılaştıııldığında olumsuz duygusal bir tepkiyi daha az güçlü olarak veren şiddet izleyicileri çok daha fazla saldırgan biçimde davranmışlardır (Moise-Titus, 1999; Kirwil ve Huesmann, 2003). Medyadaki şiddetle çok meşgul olan bireyler şiddetin kurbanına daha az sempatik olmaktadırlar. Bir araştırmada, şiddet içerikli olmayan oyunları oynayanlara göre şiddet içerikli video oyunları oynayan insanlar suçlulara daha az sert cezalar vermişlerdir (Deselms ve Altman, 2003). Medyadaki şiddete maruz kalan insanlar kurbanların yaralanmasına daha az inanmışlar (Linz, Donnerstein ve Adams, 1989) ve onlara daha az empati göstermişlerdir (Linz, Donnerstein ve Penrod, 1988). Şiddetin kurbanlarına daha az empati gösteren insanlar gerçek yaşamda bir kurbana yardım etmeye daha az istekli olmuşlardır (Molitor ve Hirsch, 1994). Şiddet içerikli televizyon programlarına maruz kalan çocuklar iki küçük çocuk arasındaki bir dövüşe, kavgaya müdahale etmede daha az istekli davranmışlardır. Benzer biçimde, medyadaki şiddete maruz kaldıktan sonra yetişkinler yoksullara yardım etmek için daha az istekli olmuşlardır (Bushman ve Anderson, 2009). Zamanla şiddete duyarsızlaşma nedeniyle, insanlar şiddete daha çok hoşgörülü ve şiddetin kurbanlarına daha az sempatik duruma gelmişlerdir. Böyle yorumlarla tutarlı araştırma insanların medyadaki şiddete daha çok maruz kalma sürecinde şiddetin gerçek gösterisine daha az psikolojik uyarılma gösterdiğini ifade etmiştir (Carnagey, Anderson ve Bushman, 2007). Empati kurbanın perspektifini edinmeyi gerektirirken, video oyunları saldırganın perspektifini benimsemeyi ilerletmektedir. Şiddet içerikli video oyunlarını oynamanın oyuncunun kurban için duyduğuempatiyi azaltmada güçlü bir etkisi olduğu gözlenmektedir (Bushman ve Anderson, 2009). 


\section{Medyadaki Şiddetin Çocuklar Üzerindeki Etkisini Arttıran Faktörler}

Nörologlar ve bilişsel psikologlar insan belleğinin çoğu kez onların çevresindeki ilgili uyarıcıların kısmen uyardığı ve biçimlendirdiği düşünceleri çağrıştıran, düşüncelerle ilişkili olan ağlardan, düğümlerden ve bağlantılardan oluşan bir ağ-şebeke olarak harekete geçtiğini ve işlev gördüğünü iddia etmektedirler. Düğümlerkavramları temsil etmekteler ve bağlantılar kavramlar arası ilişkileri ve çağrışımları ifade etmektedirler. Düşünceler, duygular ve davranışsal eğilimler tümü bellekte birbiriyle bağlantılı olmaktadırlar. Uyarıcılara maruz kalma bellekte kavramları biçimlendirebilmekte ya da aktif hale getirebilmektedir (Fiske ve Taylor, 1991). Giles (2003) bu hazırlama aşamasını uygun ipuçları sağlandığında şiddet sahneleri ile ilişkili olan belleklerin uyarılması ya da yeniden harekete geçirilmesi olarak tanımlamaktadır. Birçok faktör şiddet betimlemelerini izleme ile ilişkili olan zararlı etkilerin riskini ya arttırmakta ya da azaltmaktadır (Wilson, Kunkel, Linz ve diğerleri, 1998). Bilişsel Çağrışımsal teoriye göre bilişsel ipuçları daha çok şiddet davranışına yol açabilmektedirler. Alışılmış biçimde var olan kavramlar bellekte birlikte bağlantılı olmaktalar ve uyarıcıları yorumlamak için kullanılmaktadırlar. Örneğin, bir birey bir tabanca ile atış sporlarındaki şiddet-içermeyen bir kullanımdan çok diğer bir kişiyi öldürmeyi ya da yaralamayı düşündüğünde, tabanca çok daha fazla şiddete başvuran bir tutumda davranma olasılığını arttırmaktadır (Bartholow, Anderson, Carnagey ve diğerleri, 2005). Mutlu (1999) televizyondaki şiddet betimlemelerinin izleyicilerin daha sonra kullanımı için şiddet düşüncelerini hazırladığını ve çocuklardaki şiddet davranışını tetiklediğini ifade etmektedir. Kalp atış hızı ve kan basıncı gibi psikolojik uyarılma artabildiği gibi izleyiciler gerçek yaşamda ve medyada gözlemlenen şiddete karşı uyarılmaktadır. Saldırganlığın uyarılmanın iki olası nedeni olan (a) uyarı aktarmayla ya da iletmeyle (Zillmann, 1983) ve (b) genel uyarılmayla (Berkowitz, 1993) hızla artabildiği gözlenmektedir. Bilişsel gelişim ile ilişkili olan teoriler daha küçük çocukların sosyal senaryolarının, şemalarının ve inançlarının daha az belli olduğunu ve medyadaki şiddete maruz kalmanın etkileri yönünde daha çok korunmasız, daha çok yaralanabilir olduğunu ileri sürmüşlerdir. Çocuklar daha az -iyi- gelişmiş kişilikler kadar daha az - iyi- gelişmiş nörolojik ve duygusal sistemlere sahip oldukları için, onlar şiddet betimlemelerine tekrar tekrar maruz kalmaları ile ilişkili olan zararlı etkilere maruz kaldıklarında daha çok kolayca değişebilmektedirler. Daha küçük çocukların şiddet betimlemelerinin uzun-süreli etkilerine daha çok korunmasız, yaralanabilir oldukları ve ve maruz kaldıkları gözlemlenmiştir (Huesmann, Moise-Titus, Podolski ve diğerleri, 2003; Paik ve Comstock, 1994). Bazı sinir-anatomi uzmanlarına göre televizyonu aşırı izlemenin (günde 5 saatten, haftada 7 günden daha fazla) bir çocuğun bilişi üzerinde ciddi bir bedeli olabilmektedir. Beynin limbik sistemi ya da duyusal bölümü hayal-yaratma merkezi olarak adlandırılmaktadır. Onlar çocuklar yaşamlarının yarısını bir televizyon aygıtının önünde geçirdiklerinde limbik sistemin daha yavaş geliştiğini tartışmaktadırlar. Güçlü bir limbik sistem sürekli şiddet görüntülerine karşı doğal bir savunma sağlamaktadır (Slotsve, del Carmen, Sarver ve diğerleri, 2008).Bazı sinir görüntüleme araştırmaları televizyondaki şiddete aşırı maruz kalmanın prefrontal korteks ve uyarı ile ilişkili olan beyin bölgeleriningelişimine zarar verdiğini belirlemektedirler.Medyadaki şiddetle aşırı meşgul olma beynin frontal ve limbik bölgelerinin gelişimini geciktirmekte ve duyguları ya da davranışları kontrol eden prefrontal mekanizmalardaki etkinliği azaltmada önemli bir rol oynamakta, böylece saldırganlıkta uzun-süreli bir artışa ve engelleyici kontrolde azalmaya neden olmaktadır. Duygular duyguduyarlı limbik alanlı prefrontal bölgelerin aktifleşmesi yoluyla düzenlenmektedirler (Banks, Eddy, Angstadt ve diğerleri, 2007). Prefrontal korteksçocuklukta ve ergenlikte olgunlaşmadığı içinmedyadaki şiddete aşırı maruz kalma prefrontal-limbik iletişimini bozmaktave duygu düzenlemesi üzerinde bazı zararlı etkiler yaratmaktadır (Hummer, 2015). Birçok gelişim psikologların teorize ettikleri gibi, Paik ve Comstock (1994) medyadaki şiddetin 5 yaşından daha küçük çocuklar üzerinde daha büyük etkisinin olduğuna işaret etmişlerdir. Gelişim psikologları daha küçük çocukların daha az bilişsel becerilere sahip olduklarını, hayal ve gerçekliği ayırt etmede güçlüğü yaşadıklarını ve daha az gerçek-yaşam deneyimine sahip olduklarını ileri sürmektedirler. Bununla birlikte, araştırmacılar burada daha küçük çocukların medyadaki şiddetin zararlı etkilerine karşı daha çok korunmasız olduklarını ileri süren kanıtın az olduğunu tartışmaktadırlar (Gentile, Saleem ve Anderson, 2007). İzleyicilerin yaşının medyadaki şiddete maruz kalmada onun sorumluluk düzeyinde anlamlı bir değişken olduğu düşüncesioldukça karmaşık görünmektedir. Medyadaki şiddetin etkilerinin boyutları bir izleyicinin yaşı arttıkça tutarlı olarak azalmamaktadır (Huesmann ve Taylor, 2006). Üniversite öğrencileri arasında genellikle tutarlı olan 
korunmasızlık, yaralanabilirlik düzeyi orta çocukluktaki (6-11yaş) çocuklarınkine göre daha yüksektir. Daha küçük çocukların medyadaki şiddetin zararlı etkilerine karşı daha çok korunmasız, yaralanabilir olması gerçeğine karşın, saldırganlık yaş ile birlikte değişebilmektedir. Farklı yaşlarda aynı uyarıcılara verilen tepkileri ölçmeyi amaçlayan bir araştırmada, ilkokul çocuklarına ve üniversite öğrencilerine şiddet içeren ve içermeyen aynı video oyunları oynamaları için görev verilmiş ve onlar daha sonra aynı saldırgan davranışları göstermişlerdir. Hem çocuklar hem ergenler şiddet içerikli oyunlarını oynadıktan sonra daha çok saldırgan olmuşlardır (Anderson, Gentile ve Buckley, 2007).Araştırmacılar izleyicilerin sosyoekonomik statüsünün ve zekasının televizyondaki şiddet ile meşgul olmada önemli bir rol oynadığını da tartışmaktadırlar. Daha yüksek sosyo-ekonomik statülü ve entelektüel yetenekli çocuklarla karşılaştırıldığında, daha düşük sosyo-ekonomik statülüler ve entelektüel yetenekliler sosyal normlar, eğlenme ve entelektüel ilgi ve çaba gerektiren diğer görevlerde umduğunu bulamama olmak üzere büyük olasılıkla çeşitli nedenler yüzünden televizyonu daha çok seyretmekteler ve televizyondaki şiddete daha çok tanıklık etmektedirler. Annelerin-babaların televizyon alışkanlıkları ve çocuk yetiştirme uygulamaları bir çocuğun televizyon alışkanlıklarını etkilemektedirler (Comstock ve Paik, 1991). Sert cezalandırma, çocuğu reddetme ve disiplin yokluğu gibi çocuk yetiştirme faktörleri de çocuğun saldırganlığına katkı yapmaktadırlar (Tremblay, 2000). Comstock ve Paik (1991) daha düşük sosyoekonomik statüdeki çocukların daha yüksek sosyo-ekonomik statüdeki çocukların yaptıklarına göre ortalama olarak televizyonu daha çok izlediklerini ve televizyondaki şiddetle daha çok meşgul olduklarını bildirmelerine karşın, Huesmann ve meslektaşları (2002) sosyo-ekonomik statü ve televizyon izleme arasındaki bağlantının medyadaki şiddeti izleme ile genç yetişkinlerin suç davranışları arasındaki genel ilişki için bir açıklama sağlamadığını vurgulamışlardır (Huesmann, Eron ve Dubow, 2002). Diğer yandan, Huesmann ve Taylor (2006) çocukluktaki medyadaki şiddete daha çok maruz kaldıkları için daha düşüksosyoekonomik statüdeki çocukların yetişkinlikte saldırgan biçimde davranmalarının daha büyük olasılık olduğunu ileri sürmüşlerdir.

Bir aile ortamında, anneler-babalar çocukların medyadaki şiddetle meşgul olmasında önemli bir rol oynamaktadırlar. Çocukların medyadaki şiddete maruz kalmanın deneyimi öncelikle evde olmaktadır. Onların televizyon alışkanlıkları yaşamda erken gelişmekte ve zamanla kalıcı olmaktadır. Medyadaki şiddeti izlerken diğer insanların varlığı çocuklarda saldırgan davranışın gelişimini ya kolaylaştırmakta ya da engelleyebilmektedir. Özellikle, televizyonda betimlenen şiddeti onaylayan diğer insanlarla televizyonu birlikte izleme saldırgan davranışı kolaylaştırmakta, oysa şiddeti onaylamayan diğer insanlarla birlikte izleme saldırgan davranışı engelleyebilmektedir (Berkowitz, 1986). Bazen annelerbabalar çocuklarının sürekli izledikleri programların içeriklerinin farkında olmamaktalar ve görüntülerin etkilerini kontrol etmemektedirler; örneğin, onlar öykü hakkında yorumlar sağlama ve çatışmaları çözmek için kullanılan şiddet araçlarını onaylamama gibi bazı fırsatları gözden kaçırmaktadırlar. Görece olarak, az sayıda anne-baba gösterilerin miktarına ve sayısına sınırlamaları uygulamada belirgin kuralları koymakta, çocuklarının şiddeti seyretmesini engellemekte ya da programların içeriği hakkında yorumlar sağlamaktadır (Wright, Peters ve Huston, 1990). Çocukları ile televizyon seyreden ve programların içeriğini tartışan annelerin-babaların akıl yürütmenin kullanımına girişen ve kuralları açıklayan ve çocuklarının gururuna seslenen çocuk yetiştirme stratejilerine yaklaşması olasıdır (Abelson, 1990). J. L. Singer ve D. G. Singer (1986) göredaha çok hayal gücü kuvvetli, daha yaratıcı bir aile ev halkında ve daha az saldırgan ev ortamında, çocuklar okul öncesi yıllarda televizyonu daha az seyretmekteler, boş zaman etkinliği ve eğlenmenin bir kaynağı olarak televizyonla daha az meşgul olmaktadırlar. Bu çocukların anneleri-babaları televizyon izleme ile ilişkili olan kurallarını belirlemekteler, hayal gücüne ve yaratıcılığa değer vermekteler ve fiziksel cezalandırmaya seyrek olarak başvurmaktadırlar. Singer'ler televizyonun saldırgan senaryoları tanıttığına ve pekiştirdiğine inanmaktadırlar. Engellenme ve sosyal çatışma durumları ile baş etmeleri için çocukların hayal kurma ve yaratma gücü becerileri kadar sözlü becerilerini, oyun becerilerini arttırması gerekmektedir. Bu becerileryaşamın ilk yıllarında annelerbabalar ve akranlar ile oynama, annelerin-babaların okuması ve öykü-anlatması gibi yaratıcı etkinlikler yoluyla en iyi biçimde geliştirilmektedir. Bununla birlikte, çocuklar bazı yaratıcı etkinliklerle meşgul olma yerine zamanlarının çoğunu televizyon izlemeye ayırmaktadırlar (J. L. Singer ve D. G. Singer, 1986). Televizyon izleme eğitime engel olabilmekte ve okulda başarılı olmak için etkinliklerin yerine getirilmesine doğrudan ayrılan zamandan çalabilmektedir (Murray, 1993). Eğitimciler televizyon 
izlemenin okumanın yerini alabildiğinden ve okul performansını zayıflatabildiğinden endişe duymaktadırlar (Gunter ve McAleer, 1997). Valkenburg (2001) da televizyondaki şiddete maruz kalmanın endişeye yol açtığını ve çocukların oynadığı hayal gücüne dayalı oyunlarla ilgili zamanı azalttığını bildirmiştir. Diğer yandan, Sanders (1994) televizyon betimlemelerinin çocukların hayal gücünü etkilediğini ileri sürmüştür. O çocukların hayal gücüne dayalı etkinliklerle meşgul olmadıklarını, onların yeni öyküler oluşturmaya ya da yeni oyunlar yaratmaya gerek duymadıklarını ve tüm televizyon stüdyolarının onlar için çalıştıklarını ifade etmiştir.

Araştırmacılara göre çocukların dikkatini çeken biçim ve içerik faktörleri gösterimlerin iddia edilen etkilerinin büyüklüğünü belirlemede çok önemlidir (Huesmann ve Taylor, 2006). Çocuklarda dikkati kolaylaştıran biçimde ve içerikte sunulan şiddetin ve saldırganlığın çoğu kez şiddet sahnelerinin özelliği olan hızlı hareketi, parlak renkleri ve yüksek ses gürültülerini, özelliklerini içerdiği görünmektedir (Alvarez, Huston ve Wright, 1988). Taklit edilen davranışların getirdiği sonuçla bir dereceye kadar ilişkili olan gözlemsel öğrenme medyadaki şiddetin uzun- süreli etkilerine yol açmaktadır. Genç insanlar betimlenen davranışları taklit ettiklerinde, onlar diğer insanların aldıkları ödülleri ve cezaları hayal ederek kendilerini karakterle özdeşleştirmektedirler (Bandura, 1986; Huesmann, 1997). Model örnek alınacak ya da çekici bir davranış yaptığında, izleyici model ile özdeşleştiğinde, bağlam gerçekçi olduğunda ve gözlemlenen davranış ödüllendirildiğinde televizyonda betimlenen bir davranışın edinilmesi daha olası olmaktadır (Bandura, 1977). Global bir bağlamda, medyadaki çoğu şiddet ödüllendirilmekte ve çekici medya kahramanları (1) saldırganlığın çatışmaları çözmek için iyi bir araç olduğu, (2) saldırganlığın statü sunduğu, (3) saldırganlığın eğlenceli olabildiği yönünde üçlü bir mesajı sağlayarak amaçlarını başarmak için çoğu kez şiddeti kullanmaktadırlar (Groebel, 1998). Ekrandaki bir kahraman başarıya ulaşmak için şiddeti bir araç olarak kullandığında, izleyiciler etkilenmekte ve gerçekyaşam çatışmalarını çözmek için şiddete başvurabilmektedirler (Giles, 2003). Bir televizyon seyircisi televizyondaki ya da filmlerdeki gözlemlenen saldırgan saldırgan davranış için doğrudan ödüllendirilmemekte, oysa bir video oyuncusu puanlarla, işitsel ve görsel etkilerle ve oyun düzeyleri boyunca ilerleme ile doğrudan ödüllendirilmektedir (Gentile, Saleem and Anderson, 2007). Şiddet içeriği ödüllendirilmekte ve "eğlence" olarak görülmekte ise o zaman saldırganlık düşünceleri olumlu duygular ile klasik biçimde koşullanmaktadır. İnsanlar benzer, kahraman ve çekici olarak algıladıkları bir karakter ile daha çok özdeşleşebilmektedirler (Heath, Bresolin ve Rinaldi, 1989). Onların şiddet eylemleri haklı ve sosyal olarak kabul edilebilir davranışlar olarak sunulduğunda medya karakterleri özellikle çekici rol modelleri olmaktadırlar. İleyiciler kişisel deneyimlerle onları daha kolay ilişkilendirebildikleri için gerçeğe uygun betimlemeler ile daha yakın olarak özdeşleşebilmektedirler (Geen, 2001). Şiddet içerikli video oyunlarında, oyuncular saldırgan ile güçlü biçimde özdeşleşebilmektedirler. Saldırgan merkezi karakterler genellikle kahraman olarak övülmekteler, yüceltilmekteler ve betimlenmektedirler. Son yıllarda, video oyunlarında saldırgan karakterlerin betimlenmesi gittikçe artan biçimde gerçeğe uygun olmaktadır (Gentile, Saleem ve Anderson, 2007). Televizyondaki şiddet övüldüğünde, ödüllendirildiğinde ya da ceza almadığında ve saldırganlar "iyi adamlar" ya da "süper kahramanlar" olarak betimlendiğinde saldırganlık olumlu olarak pekiştirilmektedir.Ekrandaki şiddet savunulabilir olarak betimlendiğinde, kurbanda ciddi zarar olmadığında ve şiddet eğlendirici görünmesi için yapıldığında izleyiciler saldırgan davranışı kazanmak için güdülenebilmektedirler (Strasburger, Wilson ve Jordan, 2014). Vicdan azabı, büyük pişmanlık, suçluluk, sıkıntı, eziyet, acı çekme ve üzüntü gibi olumsuz sonuçlara sahip şiddet sahnelerine göre olumsuz sonuçlarla betimlenmeyen şiddet sahnelerinin izleyicilerin saldırganlık düzeylerini arttırması daha olasıdır (Comstock, 1985). Medyadaki şiddet etkileşimlerindeki üzüntüyü ve acıyı yaşayan kurbanı seyreden izleyiciler onların duyduğu üzüntü ve acı saldırganlığı engelleyebildiği için gerçek bir kişiye karşı daha az saldırganlık hissedebilmektedirler (Baron, 1979). Televizyon izleyicileri oyuncuların amaçlarına ulaşmak için şiddete başvurduklarını ve onu bir araç olarak kullandıklarını gözlemlemektedirler.Medyadaki böyle betimlemelere uzun süreli maruz kalma problemleri çözmenin ve birilerinin amaçlarına ulaşmasının uygun bir aracı olarak şiddetin artan kabulüne yol açmaktadır(Strasburger, Wilson ve Jordan, 2014). Medya çatışmayı çözmenin ve diğerlerini yenmenin haklı bir aracı olarak şiddeti kullanan kahramanları betimlenme eğilimindedir (Comstock ve Strasburger, 1993). "Haklı" olarak sunulan televizyondaki şiddetin seyircilerde saldırgan tepkileri ortaya çıkarması daha olasıdır (Hogben, 1998). 
Çocukların medyadaki şiddet görüntülerini tıpkı "gerçek yaşamda görülen şiddet" gibi aynı olduğu yönünde algılaması ve kabul etmesi, onları şiddet ve saldırgan davranışı model almaya ve taklit etmeye motive etmektedir. Betimlemeler gibi, özdeşleşme ve gerçekçilik de izleyicilerle ilişkili olmaktadır. Görece olarak gerçekçi betimlemeler daha çok öyküleştirilen ya da hayali bir biçimde sunulanlara göre izleyicilerin saldırganlığını arttırması daha çok olasıdır. Seyrettikleri şiddet gösterilerini "gerçek yaşamdaki şiddet gibi aynı" olduğunu düşünen ya da kendilerini televizyondaki şiddet karakterleri ile özdeşleştiren çocuklar daha yüksek fiziksel ve sözlü saldırganlık puanlarına sahip olmuşlardır (Huesmann, Moise-Titus, Podolski ve diğerleri, 2003). Önce vurgulandığı gibi, araştırmacılar ve teorisyenler medyadaki şiddetin çocuklar üzerindeki etkisini arttıran faktörleri tartışmaktadırlar. Saldırganlığın öğrenilmesini teşvik eden medya konuları (a) şiddet eylemlerini yapan "iyi adamlar"ı ya da "süper kahramanlar"ı, (b) kutlanan ya da ödüllendirilen şiddeti, (c) cezalandırılmayan şiddeti, (d) savunabilir olarak betimlenen şiddeti, (e) kurbanda ciddi olmayan zarara yol açan şiddeti ve (f) eğlenceli görünmesi için yapılan şiddeti içermektedir. Diğer yandan, (a) şiddet eylemlerini yapan zararlı ya da kötü karakterler, (b) eleştirilen ve cezalandırılan şiddet, (c) adaletsiz ya da ahlaki olarak haksız olarak betimlenen şiddet, (d) kurbanda belli yaraya ve acıya neden olan şiddet (e) kurbanı seven bireylerin üzüntüsüne ve acı çekmesine yol açan şiddet saldırganlığın öğrenilmesini engellediği düşünülen medya konularıdır (Strasburger, Wilson ve Jordan, 2014).

\section{Medyadaki Şiddete Maruz Kalmanın Saldırgan Davranışın Kazanımına Etkisi İle iliş̧kili Bulgular ve Tartışmalar}

Araştırmacılar medyadaki şiddete maruz kalmanın kısa-süreli etkilerinin hazırlanmayı, uyarılmayı ve belirli davranışların doğrudan taklidini içeren süreçler nedeniyle olduğunu ileri sürmektedirler (Bushman ve Huesmann, 2001;Huesmann, 1998). Gözlemlenen dışsal bir uyarıcı beyinde bir bilişi, duyguyu ya da davranışı temsil eden bir beyin düğümünü harekete geçirmektedir (Berkowitz, 1993). Bir birey belirli bir zamanda bir şiddet eylemine maruz kaldığında, uyarılma diğer düğümlere yayılmakta ve onları harekete geçirmektedir. Beynin sinirsel ağında aktifleşmenin yayılması ile ilgili bu süreç hazırlanma olarak adlandırılmaktadır. Medyadaki şiddete maruz kalma saldırganlıkla ilişkili tüm düğüm türlerini hazırlamakta ve kısa sürede saldırganlık olasılığını arttırmaktadır. Diğer bir önemli sinirsel süreçte, bir çocuğun şiddeti gözlemlemesi taklit etme yoluyla kısa-süreli saldırgan davranış riskini arttırmaktadır (Huesmann ve Kirwil, 2007). Birçok deney medyadaki şiddete maruz kalmanın çocukların ve gençlerin daha sonra doğrudan saldırgan davranış olasılıklarını artırdığını göstermektedir (Bushman ve Huesmann, 2001; Paik ve Comstock,1994). Bjorkqvist (1985) 5-6 yaş Finlandiya'lı çocukları ya şiddet ya da şiddet içermeyen filmlere maruz bırakmıştır. Şiddet içermeyen filmi seyretmiş çocuklara göre şiddet filmi seyretmiş çocuklar diğer çocuklara vurma ya da güreşme, mücadele gibi daha çok fiziksel saldırganlığı anlamlı olarak sergilemişlerdir. Josephson (1987) bir şiddet filmi seyretmiş 7-9 yaş erkek çocukların okulda oynadıkları salon hokeyi ile ilgili bir oyunda daha çok saldırgan davranış gösterdiklerini ortaya çıkarmıştır. Leyens ve meslektaşlarının (1975) yürüttüğü diğer bir araştırmada Belçika'da suç işleyen çocukların bir okulunda şiddet içermeyen filmleri izleyenlere göre şiddet filmleri izlemiş erkek çocuklar arasında artan bir düzeyde fiziksel saldırganlık vardır. Başka bir deneysel araştırmada, liseli erkek öğrenciler ödüllü dövüşü betimleyen saldırgan bir filme tanıklık etmişlerdir. Sonra onlar diğer bir öğrenci tarafından kışkırtıldıklarında ve yüksek sese maruz kaldıklarında bir suç ortağına elektrik şoku vermişlerdir (Geen ve O'Neal, 1969).Donnerstein ve Berkowitz (1981) ya nötr bir filmi ya da şiddet içermeyen bir seks filmini seyredenlere göre şiddet içerikli bir seks filmini seyretmiş erkeklerin kadını daha yoğun olarak cezalandırdıklarını bildirmişlerdir. Araştırmacılar medyadaki şiddetin saldırgan düşünceler ya da duygular üzerine etkisini incelemekteler ve diğer insanlara karşı fiziksel olarak saldırgan davranış riskini diğerlerine karşı şiddetin kabul edilebilir olduğuna inanan gençler arasında (Huesmann ve Guerra, 1997) ve kısmen hedeflerinin "kötü" insanlar olduğuna ve onları cezalandırmanın haklı olduğuna inanmaları nedeniyle arttırdığını göstermektedirler. Diğerlerine karşı fiziksel saldırganlık için büyük riskte olan insanların kadınlar yönündeki fiziksel saldırganlığı artan bir biçimde kabul ettikleri (Lackie ve deMan, 1997), diğerlerine düşmanca amaç atfettikleri (Dodge ve Frame, 1982), intikam, öç almanın "değerli" olduğuna inandıkları (Nisbett ve Cohen, 1996) ve şiddetin hayalini kurdukları bulunmuştur (Rosenfeld, Huesmann, Eron ve diğerleri, 1982). Medyadaki şiddete maruz kalma hem çocuklarda hem 
daha büyük gençlerde saldırgan düşünceleri doğrudan arttırabilmekte ve böylece onları saldırgan davranışa daha hoşgörülü yapmaktadır. Diğer bir araştırmada, nötr bir filmi seyretmiş çocuklara göre televizyondaki bir şiddet programını seyretmiş çocuklar bir kavgaya bir dövüşe başlamış bir ikili okul öncesi çocuğa müdahale etmeye ve bir yetişkini çağırmaya daha az istekli olmuşlardır (Thomas ve Drabman, 1975). Benzer olarak, Malamuth ve Check (1981) şiddet içerikli seks sahnelerine maruz kalmanın erkek bireylerin birkaç gün sonra kadınlara karşı fiziksel şiddeti kabul etmesini arttırdığını gösteren bulguları elde etmişlerdir. Araştırmacılar şiddet içeren video oyunlarının ergenler üzerindeki etkisini test etmek için bazı çalışmalar da yürütmektedirler. 14 yaşında Hollandalı ergen erkekler üzerinde yürüttükleri bir araştırmada, Konijn, Bijnank ve Bushman (2007) şiddet içermeyen oyun oynayanlara göre şiddet içerikli video oyunları oynayan ve özellikle video oyun karakteri ile özdeşleşen ergenlerin daha çok saldırgan biçimde davrandıklarını ve diğer erkek çocuklarda kalıcı işitme kayıbına neden olabilecek daha yoğun ve daha gürültülü ses patlamalarını verdiklerini bulmuşlardır. illkokul öğrencileri ile ilgili bir boylamsal çalışma okul yılında şiddet içerikli video oyununa ilk maruz kalmanın daha sonraki okul yılında çocukların fiziksel dövüşmelerle meşgul olma riskini yaklaşık olarak iki kat arttırdığını ortaya çıkarmıştır (Anderson, Gentile ve Buckley, 2007). Gentile ve meslektaşlarının (2004) yürttüğü 607 ergenle ilgili bir araştırmada, şiddet içerikli video oyunları oynamayan çok düşmanca öğrencilerle karşılaştırıldığında saldırgan ya da düşmanca kişilik özelliğinin üst çeyreğinde olan öğrenciler şiddet içerikli video oyunlarını çok oynadıklarında fiziksel dövüşlerinin riskini iki kat arttırmışlardır. Oysa, şiddet içerikli video oyunları oynamayan diğer düşük derecede düşmanca öğrencilerle karşılaştırıldığında en az derecede düşmanca öğrenciler (alt çeyrek) şiddet içerikli video oyunu oynadıklarında dövüşlere girme olasılığı 10 kat daha çok olmuştur (Gentile, Lynch, Linder ve diğerleri, 2004). İlköğretim okullarında 4. sınıftan 8. sınıfa kadar öğrencilerin elektronik oyun-oynama alışkanlıklarını inceleyen bir araştırmada, çocukların üçte ikisinin favorileri olarak şiddet oyunlarını seçtikleri bulunmuştur (Funk, Flores, Buchman ve diğerleri, 1999). Shibuya ve Sakamoto (2003) Japon 5. sınıf öğrencilerinin oynadıkları en popüler video oyunlarının büyük bir çoğunluğunun şiddet içerdiğini ifade etmişlerdir. Şiddetin dakika başına oranının en çok şiddet içerikli televizyon programlarına ya da filmlere göre video oyunlarında çok daha fazla olduğu bildirilmektedir. Kızlarla karşılaştırıldığında, erkekler medyadaki şiddeti daha çekici bulmaktalar ve daha büyük bir ilgi göstermektedirler (Valkenburg ve Janssen, 1999). Bununla birlikte, medyanın "XMen, Batman, Spiderman, Superman" gibi, başrol karakterler olarak erkek seyircilere hitap etme ve erkekleri kullanma eğilimi nedeniyle kadınlara göre erkekler medyadaki şiddet içerikli eğlenceleri daha güçlü biçimde çekici bulabilmektedirler. Burada şiddet içeren video oyunlarını genelde tercih etmede cinsiyet farklılığı olmamasına karşın, erkekler insan şiddetini tercih ederlerken, kızların kurgu şiddeti tercih ettikleri bulunmuştur (Funk ve Buchman, 1996). Kadınlarla karşılaştırıldığında, erkeklere "Betmen" gibi "adaleti yeniden kuran" şiddet içerikli programlar daha çok çekici gelmiştir. Bununla birlikte erkekler ve kadınlar "komedi şiddeti"ni eşit biçimde çekici bulmuşlardır (Cantor, 1998). Alan ve boylamsal araştırmalar da medyadaki şiddetin izleyiciler üzerindeki etkisine işaret etmektedirler. Kanada'da yürütülen bir diğer alan çalışmasında, araştırmacılar Kanada'ın Notel kasabasına televizyon girişinden sonra hem sözlü hem fiziksel saldırganlığın çocuklar arasında anlamlı olarak arttığını bulmuşlardır (Joy, Kimball ve Zabrack, 1986). Televizondaki şiddet ve saldırgan davranış arasındaki ilişki diğer uluslarda da belgelenmektedir. 8 farklı ülkeden 30.000'den daha çok ergenle ilgili geniş-ölçekli bir araştırmada, Kuntsche ve meslektaşları (2006) çok televizyon izlemenin artan sözlü saldırganlıkla ve sözlü zorbalıkla, kabadayılıkla anlamlı olarak ilişkili olduğunu belirlemişlerdir. Daha önceki çalışmaların birinde Huesmann ve meslektaşları 22 yıllık bir dönem süresince bir grup çocuk gözlemlemişlerdir (Huesmann ve Eron, 1986; Lefkowitz, Eron, Walder ve diğerleri, 1977). İlk çalışma 1963'de New York'da 875 üçüncü sınıf öğrencisi (8 yaş) ile ilgili bir örneklemle başlamıştır. Annenin-babanın kullandığı cezalandırma ve bakım kadar zekayı, sosyo-ekonomik statüyü, annenin-babanın sergilediği saldırganlığı içeren potansiyel ilgili faktörler istatistiksel olarak kontrol edildiğinde, onların medyadaki şiddete 8 yaşlarında maruz kalması 11 ve 22 yıl sonra onların saldırgan davranışı ile karşılıklı ilişkili olmuştur. Bulgular ilk çocuklukta şiddete tekrar tekrar maruz kalmanın 19 yaşta daha yüksek düzeylerdeki saldırganlığı tahmin edici olduğunu ortaya çıkarmıştır. Aynı grup 10 yıl sonra araştırılmış ve sonuçlar burada 8 yaşta televizyondaki şiddeti izleme ile erkekler arasında 30 yaşta kendisinin-bildirdiği saldırganlık arasındaki bir ilişkinin olduğunu ortaya çıkarmıştır (Huesmann ve Miller, 1994). Ayrı bir kültür çalışmasında, Huesmann ve Eron (1986) 
Avustralya'da, Finlandiya'da, İsral'de, Polonya'da ve Birleşik Devletler'de üç yıllık bir dönemde 6-8 ve 811 yaş 1000'den daha fazla orta-sınıf çocukları gözlemlemişlerdir. Bir çocuğun başlangıçtaki saldırganlık düzeyi kontrol edildikten sonra bile, Avustralya dışında her ülke için, televizyondaki şiddeti ilk olarak izleme ile sonraki daha yüksek saldırgan davranış anlamlı biçimde ilişkili olmuştur (Huesmann ve Eron, 1986; Huesmann, Moise-Titus, Podolski ve diğerleri, 2003). Bir boylamsal araştırmada, Huesmann ve meslektaşları 6-9 yaşlarda 500 ilkokul çocuğu ile görüşmüşler ve onları 15 yıl sonra tekrar incelemişlerdir. Yine, hem erkekler hem kadınlar için, araştırmacılar çocuklukta medyadaki şiddete çok maruz kalma ile genç yetişkinlikteki fiziksel, sözlü ve dolaylı şiddet davranışının bileşik bir ölçüsü arasındaki anlamlı karşılıklı ilişkileri bulmuşlardır (Huesmann, Moise-Titus, Podolski ve diğerleri, 2003). Singer ve Singer (1981) bir yıl süresince yaklaşık olarak 50 farklı anaokulundan 141 öğrenciyi incelemişlerdir. Araştırmacılar çocukların televizyondaki şiddeti izlemesinin okuldaki serbest oyunda gözlendiği gibi onların sonraki saldırgan davranışı ile ilişkili olduğunu bildirmişlerdir.Sonraki bir araştırmada, Singer, Singer ve Rapaczynski (1984) 4 yaştan 9 yaşa kadar 63 erkek ve kız çocuğunu izlemişlerdir.Tekrar, onlar en çok şiddet içerikli programı seyretmiş okul öncesi çocukların 9 yaşlarında en çok saldırgan davranış sergilediklerini ortaya çıkarmışlardır. Diğer yandan,Ostrov ve meslektaşları (2006) anaokulu çocuklarının medyadaki şiddete maruz kalmasının erkekler arasında sonraki fiziksel saldırganlık ile ve kızlar arasında sonraki sosyal ya da ilişkisel saldırganlık ile olumlu biçimde ilişkili olduğunu bulmuşlardır. Yeni Zelanda'da, Dunedin'de yürütülmüş geniş-ölçekli bir araştırmada, Robertson ve meslektaşları (2013) 1972-1973 doğumlu 1037 bireyi belirlemişler ve onları doğumdan 26 yaşa kadar düzenli aralıklarla değerlendirmişlerdir. Sonuçlar televizyonu daha az izleyenlerle karşılaştırıldığında 5 ve 15 yaşlar arasında televizyonu seyretmeye daha çok zaman harcamış genç yetişkinlerin büyük olasılıkla anlamlı biçimde daha çok anti-sosyal kişilik bozukluklarına, daha çok suçla ilgili yargılanmalara ve daha çok saldırgan kişilik özelliklerine sahip olduklarını ortaya çıkarmışlardır (Robertson, McAnally ve Hancox, 2013). Almanya'da7. ve 8. sınıf öğrencileri ile ilgili bir araştırmada, Krahe ve Möller (2010) medyadaki şiddete alışkanlıkla daha çok maruz kaldıklarını bildiren ergenlerin daha yüksek fiziksel saldırganlık ve daha düşük empati gösterdiklerini ileri sürmüşlerdir. Diğer bir araştırmada 3. 4. 5. sınıf çocuklarının okul yılında medyadaki şiddete ilk maruz kalması daha sonraki okul yılındaki daha yüksek sözlü saldırgan davranışı, daha yüksek ilişkisel saldırgan davranışı, daha yüksek fiziksel saldırgan davranışı ve daha az sosyal yanlı davranışı tahmin etmiştir (Gentile, Coyne ve Walsh, 2011). Çocuklukta ve ergenlikte medyadaki şiddeti seyretmiş suçlu-olmayan lise öğrencileri ve suçlu çocuklar yetişkinlikte şiddet davranışı ve genel saldırganlığın gelişimi için artan bir risktedirler (Boxer, Huesmann, Bushman ve diğerleri, 2009). Metaçözümlemeler de tüm araştırmalarda gözlemlenmiş medyadaki şiddete maruz kalma ile saldırgan davranış arasındaki olumlu, anlamlı ve tutarlı bir ilişkiyi bildirmişlerdir. Paik ve Comstock (1994) 217 araştırmayı yeniden incelemişler ve orta boyutta düşünülen 0.31 genel bir etki boyutunu bulmuşlardır. Bushman ve Anderson'ın (2001) büyük ölçekli bir meta-çözümlemesi medyadaki şiddetin etkileri üzerine 212 araştırmayı incelemiş ve medyadaki şiddetin saldırganlık üzerine etkilerinin 1975'den beri zaman içerisinde arttığını bulmuştur. Medyadaki şiddete maruz kalma izleyicilerde saldırgan düşünceleri, duyguları, psikolojik uyarılmayı ve sonraki saldırgan ya da anti-sosyal davranış olasılığını arttırmaktadır. Teorisyenler ve araştırmacılar yoğunlukta derece derece artan medyadaki şiddete tekrar tekrar maruz kalmanın zamanla saldırgan davranışı geliştirmede önemli bir rol oynayan bir risk faktörü olduğunu ileri sürmektedirler.

\section{Sonuç}

Gözlemsel öğrenme ve taklit etme çocuklukta ve ergenlikte şiddet ve saldırgan davranışlar kazanmak için önemli bir rol oynamaktadır. Çocuklar kitle iletişim araçlarındaki şiddet davranışlarını gözlemleyerek ve taklit ederek fiziksel ve sözlü biçimlerde saldırgan olarak davranmayı öğrenebilmektedirler. Laboratuvar ve alan deneyleri çocukların ve gençlerin filmdeki ve televizyondaki şiddet davranışlarına maruz kalmasının daha sonra doğrudan saldırgan biçimde davranma olasılığını arttırdı̆̆ını göstermektedir. Çocuklar kitle iletişim araçlarındaki şiddet ve saldırgan davranışların tekrar tekrar gözlemlerinden yaptıkları çıkarımlar yoluyla sosyal problemleri çözme senaryolarını, düşmanca dünya şemalarını, düşmanca nitelendirme eğilimlerini ve saldırganlığı onaylayan normatif inançları geliştirebilmektedirler. 
Saldırgan senaryolar, düşmanca nitelendirilen eğilimler ve normatif inançlar çocukların saldırgan biçimde davranma olasılığını arttırmaktadırlar. Çocuklar kitle iletişim araçlarındaki şiddet ve saldırgan davranışları hayal ederek ve tekrar ederek belleğine iyice yerleştirebilmekteler ve belleğinden kolayca geri getirebilmektedirler. Kitle iletişim araçlarındaki şiddete tekrar tekrar maruz kalma belirli doğal tepkilere alışmaya ya da daha sonra şiddete duyarsızlaşmaya yol açabilmektedir. Duyarsızlaşmanın yanında birçok faktör medyadaki şiddetin çocuklar üzerindeki etkilerini arttırmaktadır. Çocuklar ödüllendirilen saldırgan davranışları gözlemlediklerinde ve gözlemlenen saldırgan davranışları tıpkı gerçek yaşamdaki gibi aynı olduğu yönünde algıladıklarında ve kötü insanlara karşı şiddet kullanmayı haklı gördüklerinde gözlemlenen modellerle daha çok özdeşleşebilmektedirler.

\section{Öneriler}

Medyadaki saldırganlığın ve şiddetin artan miktarı ve sertliği yönündeki eğilim günümüz dünyasında çocukların sağlıklı gelişimine zarar vermektedir. Çocukların ve ergenlerin sağlığı ve iyi olması, televizyon, filmler, bilgisayar oyunları ve video kasetler olmak üzere medyadaki şiddete maruz kalmaları nedeniyle risk altındadır. 7 ve 8 yaşlarına kadar çocuklar hayal ve gerçeği ayırtetmede büyük güçlük çekmektedir. Küçük çocuklar özellikle ilk çocuklukta sosyal, duygusal, bilişsel ve fiziksel gelişmesi olumsuz ve kötü etkilerden kolayca zarar görebilmektedirler. Araştırmalar şiddet programlarını daha çok seyrederek televizyonda gördükleri saldırgan eylemleri sadece taklit eden çocukların taklit edici oyunla daha çok ilişkili ve yaratıcı oyunla daha az ilişkili olduğuna işaret etmektedirler (NIMH, 1982). Şiddet programları çocukların televizyonda ya da filmlerde gördükleri davranışları oyunlarında taklit etmeye ve yeniden yapmaya teşvik etmektedirler. Bu durumlar çocukların yaratıcı ve hayal gücüne dayalı oyunlarına zarar vermekte ve böylece çocukları gelişimleri için gerekli oyunların yararlarından yoksun bırakmaktadır (Carlsson-Paige ve Levin, 1990). Oyunlarında, çocuklar saldırgan davranışları için pekiştirilen böyle karakterleri taklit etmekteler ve yaratıcı ya da refleksif düşünce olmaksızın karakterlerin senaryolarını tekrarlamaktadırlar (Eron ve Huesmann, 1987). Anneler-babalar medyadaki şiddetin çocuklar üzerindeki potansiyel zararlı etkilerini önlemede aktif bir rol almalıdırlar. Onlar çocukların televizyon ile etkileşimlerine yol gösteren ve çocuklarının medyadaki şiddete maruz kalmasını engelleyen stratejileri kullanmalıdırlar. Anneler-babalar evde bireylerin medya kullanımı için kuralları ve çocuklarla medyayı kullanma derecesini belirlemektedirler. Anneler-babalar çocukları ile televizyonu ya da diğer medyayı izlerken gösterileri birlikte değerlendirmelidirler. Onlar medya içeriğini çocukları ile konuşma ve gördüklerini çocukları ile tartışma yoluyla medyanın çocuklar üzerindeki zararlı etkilerini azaltabilmektedirler. Annelerin-babaların medyanın sunduğu şiddeti yorumlama, ayrıntılı olarak üzerinde durma ve ek bilgi sağlama çabalarının, medyadaki şiddetin çocuklar üzerindeki olumsuz ya da zararlı etkilerini yok etmede başarılı olduğu bulunmaktadır. Daha önce de işaret edildiği gibi, araştırmalar annelerin-babaların çocuklarla birlikte programları izlemesinin ve yorum yapmasının televizyondaki şiddetin çocuklar üzerindeki etkilerini azalttığını bulmaktadırlar (Nathanson, 1999). Hükümet ya da medya endüstrisi olumlu medya içeriğini ve medyanın çocuklar üzerindeki etkileri konusunda kamu eğitimini teşvik etmelidir. Okullar medyadaki zararlı etkileri yok etmede yararlı olabildiği için medya eğitimini vermelidirler. Öğretmenler çocukların çatışmaları şiddet içermeyen biçimde çözmede beceriler geliştirmesine ve medyanın eleştirel okuyucuları olmasına yardım etmede bir sorumluluğa sahiptirler. Onlar çocuklarda eleştirel bakma becerileri geliştirebilmekteler ve çatışmaları çözmek için şiddet içermeyen stratejileri öğretebilmektedirler. Okullar, eğlence endüstrisi ya da hükümet çocukları ve ergenleri medyanın zararlı etkilerinden korumalı ve modern medyada sosyal yanlı yönleri güçlü biçimde gerçekleştirmelidirler. Medya endüstrisi ve anneler-babalar medyayı çocuklarda bilgiyi genişletmek ve olumlu sosyal değerleri geliştirmek için yapıcı biçimde kullanmalıdırlar. Anneler-babalar çocuklarının televizyon izleme alışkanlıklarını kontrol etmeli ve çocuklarını medyadaki şiddete sağlıksız maruz kalmasından ve şiddet içerikli programların olumsuz etkilerinden korumalıdırlar. 


\section{References}

Abelson, R. (1990). Determinants of parental mediation of children's television viewing. In J. Bryant (Ed.), Television and the American family(pp. 311-326). Hillsdale, NJ: Lawrence Erlbaum.

Alvarez M. M, Huston A. C, Wright J. C. (1988). Gender differences in visual attentionto television form and content. Journal of Applied Developmental Psychology. 9 (4), 459-75.

American Academy of Pediatrics (2010). Policy statement-media education. Pediatrics, 126 (5), 10121017.

Anderson, C. A.,\& Bushman, B. J. (2002b). Human aggression. Annual Review of Psychology, 53, 27-51.

Anderson, C. A., Gentile, D. A. \& Buckley, K. E. (2007). Violent Video game effects on children and adolescents: Theory, research, and public policy. New York: Oxford University Press.

Ayrancı, Ü., Köşgeroğlu, N. \& Günay, Y. (2004). Televizyonda çocukların en çok seyrettikleri saatlerde gösterilen filmlerdeki şiddet düzeyi, Anadolu Psikiyatri Dergisi, 3, 133-140.

Bailey, K., West, R., \& Anderson, C. A. (2010). A negative association between video game experience and proactive cognitive control. Psychophysiology, 47, 34-42.

Bandura, A. (1977). Social learning theory. Englewood Cliffs, NJ: Prentice-Hall.

Bandura, A. (1986). Social foundations of thought and action: a social cognitive theory. Upper Saddle River, NJ: Prentice Hall.

Bandura, A. (1997). Self-efficacy: The exercise of control. New York: WH Freeman.

Bandura, A. (2001). Social cognitive theory of mass media communication, Media Psychology, 3 (3), 265-299.

Banks, S. J., Eddy, K. T., Angstadt, M., Nathan, P. J. \& Phan, K. L. (2007). Amygdala-frontal connectivity during emotion regulation. Social Cognitive and Affective Neuroscience, 2, 303-312.

Baron, R. A. (1979). Effects of victim's pain cues, victim's race, and level of prior instigationupon physical aggression. Journal of Applied Social Psychology, 9, 103-114.

Bartholow, B. D., Anderson, C. A., Carnagey, N. L.\& Benjamin, A. J. (2005). Interactive effects of life experience and situational cues on aggression: The weapons priming effect in hunters and nonhunters. Journal of Experimental Social Psychology, 41, 48-60.

Berkowitz, L. (1986), Situational influences on reactions to observed violence. Journal of Social Issues, 42, 93-106.

Berkowitz, L. (1993). Aggression: Its causes, consequences, and control. New York: McGraw-Hill.

Bjorkqvist, K. (1985). Violent films, anxiety and aggression. Helsinki, Finland: Finnish Society of Sciences and Letters.

Bjorkqvist, K., Osterman, K. \& Kaukiainen, A. (1992). The development of direct and indirect aggressive strategies in males and females. In K. Bjorkqvist \& P. Niemela (Eds.), Of mice and women: Aspects of femaleaggression (pp. 51-64). New York: Academic Press.

Boxer, P., Huesmann, L. R., Bushman, B. J., Brien, M. O. \& Moceri, D. (2009). The role of violent media preference in cumulative developmental risk for violence and general aggression. Journal of Youth and Adolescence, 38(3), 417-428.

Bushman, B. J. \& Anderson, C. A. (2001). Media violence and the American public: Scientific facts versus media misinformation. American Psychologist, 56, 477-489.

Bushman, B. J. \& Huesmann, L. R. (2001). Effects of televised violence on aggression. In D. Singer \& J. Singer (Eds.), Handbook of children and themedia (pp. 223-254). Thousand Oaks, CA: Sage Publications.

Bushman, B. J. \& Anderson, C. A. (2009). Comfortably numb: Desensitizing effects of violent media on helping others. Psychological Science, 21(3), 273-277.

Bushman, B. J. \& Huesmann, L. R. (2010). Aggression. In S. T. Fiske, D. T. Gilbert \& G. Lindzey (Eds.), Handbook of Social Psychology(pp. 833-855). USA: John Wiley \& Sons Inc.

Cantor, J. (1998). Children's attraction to violent television programming. In J.H. Goldstein (Ed.), Why we watch: The attractions of violent entertainment(pp. 88-115). New York: Oxford University Press.

Carlsson-Paige, N.,\& D.E. Levin. 1990. Who's calling the shots? How to respond effectively to children's fascination with war play and war toys. Gabriola Island, BC, CAN: New Society. 
Carnagey, N. L., Anderson, C. A. \& Bushman, B. J. (2007). The effect of video game violence on physiological desensitization to real life violence. Journal of Experimental SocialPsychology, 43, 489-496.

Children Now. (2001). Fair play? Violence, gender and race in video games. Los Angeles: Author.

Comstock, G. A. (1985). Television and film violence. In S. Apter \& A. Goldstein (Eds.), Youth violence: Programs and prospects. New York: Perhamon.

Comstock, G. \& Paik, H. (1991). Television and the American child. New York: Academic Press.

Comstock G. \& Strasburger V. C. (1993). Media violence: Q \& A. Adolescent Medicine,4 (3), 495-510.

Crick, N. R. \& Dodge, K. A. (1994). A review and reformulation of social information processing mechanisms in children's adjustment. Psychological Bulletin, 115, 74-101.

Deselms, J. L. \& Altman, J. D. (2003). Immediate and prolonged effects of videogame violence. Journal of Applied Social Psychology, 33, 1553-1563.

Dodge, K. A. \& Frame, C. L. (1982). Social cognitive biases and deficits in aggressive boys. Child Development, 53, 620-635.

Dodge, K. A., Pettit, G. S., Bates, J. E. \& Valente, E. (1995). Social information processing patterns partially mediate the effect of early physical abuse on later conduct problems. Journal of Abnormal Psychology, 104, 632-643.

Donnerstein, E. \& Berkowitz, L. (1981). Victim reactions in aggressive erotic films as a factor in violence against women. Journal of Personality andSocial Psychology, 41, 710-724.

Eron, L. \& Huesmann, L. (1987). Television as a source of maltreatment of children. School Psychology Review, 16, 195-202

Fiske, S. T. \& Taylor, S. E. (1991). Social cognition. New York: McGraw-Hill.

Funk, J. B. \& Buchman, D. D. (1996). Playing violent video and computer games and adolescent selfconcept. Journal of Communication, 46(2), 19-32.

Funk, J. B., Flores, G., Buchman, D. D. \& Germann, J.N. (1999). Rating electronic games: Violence is in the eye of the beholder. Youth \& Society, 30, 283-312.

Geen, R. G. \& O'Neal, E. C. (1969). Activation of cue-elicited aggression by general arousal. Journal of Personality and Social Psychology, 11, 289-292.

Geen, R. G. (2001). Human aggression. Philadelphia: Open University Press.

Gentile, D. A., Lynch, P. L., Linder, J. R. \& Walsh, D. A. (2004). The effects of violent video game habits on adolescent hostility, aggressive behaviors, and school performance. Journal ofAdolescence, 27, 522.

Gentile, D. A., Saleem, M. \& Anderson, C. A. (2007). Public policy and the effects of media violence on children. Social Issues and Policy Review, 1, 15-61.

Gentile, D. A., Coyne, S. \& Walsh, D. A. (2011).Media violence, physical aggression, and relational aggression in school age children: A short-term longitudinal study. Aggressive Behavior, 37, 193206.

Gerbner, G., Gross, L., Morgan, M. \& Signorielli, N. (1994). Growing up with television: The cultivation perspective. In J. Bryant \& D. Zillmann (Eds.), Media effects (pp. 17-41). Hillsdale, NJ: Erlbaum.

Giles, D. (2003). Media psychology. Hillsdale, NJ: Lawrence Erlbaum Associates.

Groebel, J. (1998). The UNESCO global study on media violence: A joint project of UNESCO, the World Organization of the Scout Movement and Utrecht University, The Netherlands. Reportpresented to the Director General of UNESCO, UNESCO, Paris.

Guerra, N. G., Huesmann, L. R., \& Spindler, A. J. (2003). Community violence exposure, social cognition, and aggression among urban elementary school children. Child Development, 74(5), 1507-1522.

Gunter, B. \& McAleer, J. (1997). Children and television. New York: Routledge.

Heath, L., Bresolin, L. B. \& Rinaldi, R. C. (1989). Effects of media violence on children. Archives of General Psychiatry, 46, 376-379.

Hogben, M. (1998). Factors moderating the effect of television aggression on viewer behavior. Communication Research, 25, 220-247.

Huesmann, L. R., Lefkowitz, M. M. \& Eron, L. D. (1978). Sum of MMPI scales F, 4, and 9 as a measure of aggression. Journal of Consulting andClinical Psychology, 46, 1071-1078. 
Huesmann, L. R., Eron, L. D., Lefkowitz, M. M., \& Walder, L. O. (1984). Stability of aggression over time and generations. Developmental Psychology,20, 1120-1134.

Huesmann, L. R. \& Eron, L. D. (1986). Television and the aggressive child: A cross-national comparison. Hillsdale, NJ: Erlbaum.

Huesmann, L. R. (1988). An information processing model for the development of aggression. Aggressive Behavior, 14, 13-24.

Huesmann, L. R. \& Miller, L. S. (1994). Long-term effects of repeated exposure to media violence in childhood. In L. R. Huesmann (Ed.), Aggressive behavior: Current perspectives (pp. 153-186). New York: Plenum Press.

Huesmann, L. R. (1997). Observational learning of violent behavior: Social and biosocial processes (pp. 69-88). In A. Raine, P. A. Brennen, D. P. Farrington, \& S. A. Mednick (Eds.),Biosocial bases of violence. London: Plenum.

Huesmann, L. R. \& Guerra, N. G. (1997). Chidren's normative beliefs about aggression and aggressive behavior, Journal of Personality and Social Psychology, 72 (2), 408-419.

Huesmann, L. R. (1998). The role of social information processing and cognitive schema in the acquisition and maintenance of habitual aggressive behavior. In R.G. Geen \& E. Donnerstein (Eds.), Human aggression:Theories, research, and implications for social policy (pp. 73-109). New York: Academic Press.

Huesmann, L. R., Eron, L. D. \& Dubow, E. F. (2002). Childhood predictors of adult criminality: Are all risk factors reflected in childhood aggressiveness? Criminal Behavior and Mental Health, 12 (3), 185208.

Huesmann, L. R., Moise-Titus, J., Podolski, C. L. \& Eron, L. (2003). Longitudinal relations between children's exposure to TV violence and their aggressive and violent behavior in young adulthood: 1977-1992. Developmental Psychology, 39, 201-221.

Huesmann, L. R. \& Taylor, L. D. (2006). The role of media violence in violent behavior. Annual Review of Public Health, 27, 393-415.

Huesmann, L. R. \& Kirwil, L. (2007). Why observing violence increases the risk of violent behavior by the observer. In D. J. Flannery, A. T. Vazsony \& I. Waldman (Eds.), The Cambridge handbook of violent behavior and aggression (pp. 545-570). Cambridge: Cambridge University Press.

Hummer, T. A. (2015). Media violence effects on brain development: What neuroimaging has revealed and what lies ahead. American Behavioral Scientist, 59(4), 1790-1806.

Josephson, W. L. (1987). Television violence and children's aggression: Testing the priming, social script, and disinhibition predictions. Journalof Personality and Social Psychology, 53, 882-890.

Joy, L. A., Kimball, M. M. \& Zabrack, M. L. (1986). Television and children's aggressive behavior. In T.M. Williams (Ed.), The impact of television: Anatural experiment in three communities (pp. 303-360). San Diego, CA: Academic Press.

Kirwil, L. \& Huesmann, L. R. (2003, May). The relation between aggressiveness and emotional reactions to observed violence. Paper presented at theannual meeting of the Midwestern Psychological Association, Chicago.

Konijn, E. A., Bijnank, M. N. \& Bushman, B. J. (2007). I wish I were a warrior: The role ofwishful identification in the effects of violent video games on aggression in adolescent boys. Developmental Psychology, 43, 1038-1044.

Krahe, B. \& Möller, I. (2010). Longitudinal effects of media violence on aggression and empathy among German adolescents. Journal of Applied Developmental Psychology, 31, 401-409.

Kuntsche, E., Pickett, W., Overpeck, M., Craig, W., Boyce, W., \& Gaspar de Matos, M. (2006). Television viewing and forms of bullying among adolescents from eight countries. Journal of Adolescent Health, 39, 908-915.

Lackie, L. \& de Man, A.F. (1997). Correlates of sexual aggression among male university students. Sex Roles, 37, 451-457.

Lefkowitz, M. M., Eron, L. D., Walder, L. O. \& Huesmann, L. R. (1977). Growing up to be violent: A longitudinal study of the development ofaggression. New York: Pergamon Press. 
Leyens, J. P., Camino, L., Parke, R. D. \& Berkowitz, L. (1975). Effects of movie violence on aggression in a field setting as a function of group dominance and cohesion. Journal of Personality and Social Psychology,32, 346-360.

Liebert, R. M. \& Spiegler, M. D. (1990). Personality: Strategies and issues. Belmont CAL: Wadsworth.

Linder, J. \& Lyle, K. (2011). A content analysis of indirect, verbal and physical aggression in television programs popular among school-aged girls. American Journal of Media Psychology, 4, 24-42.

Linz, D. G., Donnerstein, E. \& Penrod, S. (1988). Effects of long-term exposure to violent and sexually degrading depictions of women. Journal of Personality and SocialPsychology, 55, 758-768.

Linz, D. G., Donnerstein, E., \& Adams, S. M. (1989). Physiological desensitization and judgments about female victims of violence. Human Communication Research, 15, 509-522.

Malamuth, N. M. \& Check, J. V. P. (1981). The effects of mass media exposure on acceptance of violence against women: A field experiment. Journal ofResearch in Personality, 15, 436-446.

Martins, N. \& Wilson, B. J. (2012a). Mean on the screen: Social aggression in programs popular with children. Journal of Communication, 62, 991-1009.

Moise - Titus, J. (1999). The role of negative emotions in the media violence - aggression relation . Unpublished doctoral dissertation, University of Michigan, Ann Arbor.

Molitor, F. \& Hirsch, K. W. (1994). Children's toleration of real-life aggression after exposure to media violence: A replication of the Drabman and Thomas studies. Child StudyJournal, 24, 191-207.

Murray, J. (1993). The developing child in a multimedia society. In G. L. Berry \& J. K. Asamen (Eds.), Children and television images in a changing sociocultural world (pp. 9-22). Newbury Park, CA: Sage Publications.

Mutlu, E. (1999). Televizyon ve Toplum. Türkiye Radyo ve Televizyon Kurumu. Ankara.

Nathanson, A. I. (1999). Identifying and explaining the relationship between parental mediation and children's aggression. Communication Research, 26, 124-143.

National Institute of Mental Health. (1982). Television and behavior: Ten years of scientific progress and implications for the eighties (Vol. 1): Summary report. Washington, DC: U.S. GovernmentPrinting Office.

Nisbett, R. E. \& Cohen, D. (1996). Culture of honor: The psychology of violence in the South. Boulder, CO: Westview Press.

Ostrov, J. M., Gentile, D. A. \& Crick, N. R. (2006). Media exposure, aggression and prosocial behavior during early childhood: A longitudinal study. Social Development, 15, 612-627.

Ostrow, J. M. \& Godleski, S. A. (2010). Toward an integrated gender-linked model of aggression subtypes in early and middle childhood. Psychological Review, 117(1), 233-242.

Paik, H. \& Comstock, G. (1994). The effects of television violence on antisocial behavior: A metaanalysis. Communication Research, 21(4), 516-546.

Rideout, V. J., Vandewater, E. A. \& Wartella, E. A. (2003). Zero to six: Electronic media in the lives of infants, toddlers, and preschoolers. MenloPark, CA: Kaiser Family Foundation.

Rideout V. J., Foehr, U. G. \& Roberts, D. F. (2010). Generation M2: Media in the lives of 8-to 18-year olds. Menlo Park, CA: Kaiser Family Foundation.

Rizzolati, G., Fadiga, L., Gallese, V. \& Fogassi, L. (1996). Premotor cortex and the recognition of motor actions. Cognitive Brain Research, 3, 131-141.

Rizzolatti, G. \& Craighero, L. (2004). The mirror-neuron system. Annual Review of Neuroscience, 27, 169192.

Robertson, L. A., McAnally, H. M. and Hancox, R. J. (2013). Childhood and adolescent television viewing and antisocial behavior in early adulthood. Pediatrics, 131, 439-446.

Rosenfeld, E., Huesmann, L. R., Eron, L. D. \& Torney-Purta, J. V. (1982). Measuring patterns of fantasy behaviors in children. Journal of Personalityand Social Psychology, 42, 347-366.

RTÜK. (2009). Televizyon İleme Eğilimleri Araştırması-2, Ankara.

Sanders, B. (1994). A is for ox. Violence, electronic media, and the silencing of the writtenword. New York: Pantheon Books.

Satcher, D. (2001). Youth violence: A report of the Surgeon General. Retrieved April 9, 2008 fromhttp://www.surgeongeneral.gov/library/youthviolence/report.html=message. 
Shibuya, A. \& Sakamoto, A. (2003). The quantity and context of video game violence in Japan: Toward creating an ethical standard. In K. Arai (Ed.), Social contributions and responsibilities of simulation \& gaming (pp. 305-314). Tokyo: Japan Association of Simulation and Gaming.

Singer, J. L.,\& Singer, D. G. (1981). Television, imagination, and aggression: A study of preschoolers' play . Hillsdale, NJ: Lawrence Erlbaum.

Singer, J. L. \& Singer, D. G. (1986). Family experiences and television viewing as predictors of children's imagination, restlessness, and aggression, Journal of Social Issues, 42 (3), 107-124.

Singer, J. L., Singer, D. G., \& Rapaczynski, W. (1984). Family patterns and television viewing as predictors of children's beliefs and aggression. Journal of Communication, 34 (2), 73-89.

Slotsve, T., del Carmen, A., Sarver, M. \& Villareal-Watkins, R. (2008). Television Violence and Aggression: A Retrospective Study. Southwest Journal of Criminal Justice, 5 (1), 22-49.

Spieker, S. J., Campbell, S. B., Vandergrift, N., Pierce, K. M., Caufmann, E., Susman, E. J. \& Roisman, G. I. (2012). Relational aggression in middle childhood: Predictors and adolescent outcomes. Social Development, 21(2), 354-375.

Strasburger, V. C. \& Wilson, B. J. (2014). Television violence: 60 years of research. In: D. A. Gentile (Ed.), Media Violence and Children(pp. 57-86). Westport, CT: Praeger.

Strasburger, V. C., Wilson, B. J. \& Jordan, A. B. (2014). Children, adolescents, and the media. Los Angeles, CA: Sage.

Straus, M. A., Gelles, R. J. \& Steinmetz, S. K. (1980). Behind closed doors: Violence in the American family (Appendix B). Garden City, NY:Anchor Books.

Swing, E. L. \& Anderson, C. A. (2010). Media violence and the development of aggressive behavior. In M. DeLisi \& K. M. Beaver (Eds.) Criminological Theory: A Life-Course Approach. (pp. 87-108). Jones \& Bartlett. Sudbury, MA: Jonesand Bartlett.

Thomas, M. H. \& Drabman, R. S. (1975). Toleration of real life aggression as a function of exposure to televised violence and age of subject. Merrill-Palmer Quarterly, 21, 227-232.

Tiegs, E. W. \& Clark, W. W. (1970). California Achievement Test. New York: McGraw-Hill.

Tremblay, R. E. (2000). The development of aggressive behavior during childhood: What have we learned in the past century? InternationalJournal of Behavioral Development, 24, 129-141.

Valkenburg, P. M.,\& Janssen, S. C. (1999). What do children value in entertainment programs? A crosscultural investigation. Journal of Communication, 49, 3-21.

Valkenburg, P.M. (2001). Television and the child's developing imagination. In D. G. Singer\& J. L. Singer (Eds.), Handbook of children and the media (pp. 121-134). Thousand Oaks, CA: Sage.

Vandewater, E. A., Rideout, V. J., Wartella, E. A., Huang, X., Lee, J. H., Shim, M. (2007). Digital childhood: electronic media and technology use among infants, toddlers, and preschoolers. Pediatrics, 119(5), 1006-1015.

Warner, W. L., Meeker, M. \& Eells, K. (1960). Social class in America. New York: Harcourt.

Wilson, B. J., Kunkel, D., Linz, D., Potter, J., Donnerstein, E., Smith, S. L., Blumenthal, E. \& Berry, M. (1998). Violence in television programming overall: University of California, Santa Barbara study. In M. Seawall (Ed.), National television violence study (Vol. 2, pp. 3-204). Thousand Oaks, CA: Sage Publications.

Wilson, B. J., Smith, S. L., Potter, W. J., Kunkel, D., Linz, D., Colvin, C. M. \& Donnerstein, E. (2002). Violence in children's television programming: Assessing the risks. Journal of Communication, 52(1), 5-35.

Wright, J. C., St. Peters, M. \& Huston, A. C. (1990). Family television use and its relation to children's cognitive skills and social behavior. In J. Bryant (Ed.), Television and the American family (pp. 227252). Hillsdale, NJ: Lawrence Erlbaum.

Zillmann, D. (1983). Transfer of excitation in emotional behavior. In J. T. Cacioppo \& R. E. Petty (Eds.), Social psychophysiology: A sourcebook(pp. 215-240). New York: Guilford Press. 